\title{
Uluslararası İlişkiler Dergisinin Bibliyometrik Analizi (2004-2017)
}

\author{
Bibliometric Analysis of Journal of Uluslararası Ilişkiler \\ (International Relations) (2004-2017)
}

\section{Elvan ÇOKISŞLER}

Dr. Ar. Gör., Uluslararası İlişkiler Bölümü, Adnan Menderes Üniversitesi

\section{Bu makaleye atıf için}

Çokişler, Elvan, "Uluslararası İlişkiler Dergisinin Bibliyometrik Analizi (2004-2017)", Uluslararası İlişkiler, Cilt 16, Say1 64, 2019, s. 29-56, DOI: 10.33458/uidergisi.652899

Makaleye Erişim İçin: https://dx.doi.org/10.33458/uidergisi.652899

\author{
Makale Gönderim: 14 Ağustos 2018 \\ Son Düzeltme: 07 Ağustos 2019 \\ İnternet Yayım: 01 Aralık 2019 \\ Basım Tarihi: 01 Aralık 2019
}

\section{Uluslararası İlişkiler Konseyi Derneği | Uluslararası İlişkiler \\ E-Posta: bilgi@uidergisi.com.tr}

Bu makalenin tüm hakları Uluslararası İişkiler Konseyi Derneğỉne aittir. Önceden yazılı izin almadan hiçbir iletişim, kopyalama ya da yayın sistemi kullanılarak yeniden yayımlanamaz, çoğaltılamaz, dağıtılamaz, satılamaz veya herhangi bir şekilde kamunun ücretli/ücretsiz kullanımına sunulamaz. Akademik amaçlı alıntılar bu kuralın dışındadır. Yazıda belirtilen fikirler yalnızca yazarına/yazarlarına aittir. UİK Derneğini, editörleri ve diğer yazarları bağlamaz. 


\title{
Uluslararası İlişkiler Dergisinin Bibliyometrik Analizi (2004-2017)
}

\author{
Elvan ÇOKIŞLER \\ Dr. Ar. Gör., Adnan Menderes Üniversitesi, Nazilli İİBF, Uluslararası İlişkiler Bölümü, Aydın. \\ E-posta:elvanoz@hotmail.com
}

\section{ÖZET}

Bu araştırma, Uluslararası İlişkiler Dergisi’ni bibliyometrik analiz tekniği ile incelemektedir. Bu amaçla Derginin 14 yıllık yayın hayatı, 4-5-5 yıllık üç ara döneme ayrılmış ve yayımlanan 56 sayıda yer alan toplam 316 makale ve 319 yazar hakkında bibliyometrik veriler derlenmiştir. Makaleler dil, araştırma türü, ana bilim dalı, anahtar kelimeler, konu, ele aldıkları teoriler, coğrafi bölgeler ve ülkeler; yazarlar ise ülkeleri, unvanları, cinsiyetleri, kurumları ile kurumsal ve kişisel üretkenlikleri gibi ölçütler baz alınarak değerlendirilmiş, dönemler arası değişimler ortaya çıkarılmıştır. Bulgular, Türkiye'deki Uluslararası İlişkiler disiplininin önemli bir kesitini Dergi özelinde sunmaktadır.

Anahtar Kelimeler: Uluslararası İlişkiler Disiplini, Bibliyometrik Analiz, Uluslararası İlişkiler Dergisi

\section{Bibliometric Analysis of Journal of Uluslararası Iliş̧kiler (International Relations) (2004-2017)}

\begin{abstract}
This research analyzes the journal of Uluslararası İlişkiler (International Relations) using bibliometrics. 14year span of the journal was divided into three intervals of 4-5-5 years, and bibliometric data relating to a total of 316 articles and 319 authors throughout the 56 issues published so far were gathered. The articles were evaluated based upon parameters such as language, type of research, department, keywords, topics, theories, geographical regions and countries while the authors were evaluated on the basis of their origins, titles, gender, institutions as well as institutional and personal productivity. Changes between the intervals were consequently determined. The findings present an important journal-specific cross-section of the discipline of International Relations in Turkey.
\end{abstract}

Keywords: International Relations Discipline, Bibliometric Analysis, Journal of International Relations

\footnotetext{
Bu çalışma Adnan Menderes Üniversitesi Bilimsel Araştırma Projeleri Koordinasyon Birimi tarafından desteklenmiştir. Proje No: İ́BF-18015.
} 


\section{Giriş}

Günümüzde bilimsel bilginin üretildiği ve yayıldığı en önemli mecra hakem denetimli akademik dergilerdir. Her bilimsel alanın önde gelen dergileri hakkında, nesnel verilerin bilimsel yöntemlerle ortaya konması, sonuçların kıyaslanması ve değerlendirilmesi, disiplinin gelişim ve değişim aşamalarının anlaşılmasını sağlar. Bu nedenle, bir alanda üretilmiş bilginin, bu bilginin aktarılmasını ve yayılmasını sağlayan kişi, kurum ve yayınların performanslarının ve alandaki eğilimlerin anlaşılması için belirli zaman aralıklarında alanın önde gelen dergileri aracılığıyla incelenmesi önerilmiştir. ${ }^{1} \mathrm{Bu}$ amaçla en sık kullanılan yöntem ise bibliyometri veya bir diğer ifadeyle bibliyometrik analizdir.

Çeşitli istatistik programlarının gelişmesine bağlı olarak son yıllarda kullanımı giderek artan bibliyometrik analiz, "matematiksel ve istatistiksel tekniklerle, yayınlanmış dergi, kitap vb. bilimsel bilgi paylaşım araçlarının incelenmesinde kullanılan yöntem”2 olarak tanımlanmaktadır. Bu yöntemle ulaşılan bulgular, ülke ve kurumların kıyaslamalarında kullanılmakta, ${ }^{3}$ bu sayede disiplinin fotoğrafı çekilebilmekte $^{4}$ ve dergilerin yayın dinamikleri anlaşılabilmektedir. ${ }^{5}$

Uluslararası İlişkiler disiplininde alan dergilerinin bibliyometrik analizinin yapıldığı çok sayıda araştırma mevcuttur. Breuning vd., ${ }^{6}$ Goldmann, ${ }^{7}$ Maliniak vd., ${ }^{8}$ Wæver ${ }^{9}$ alanın önde gelen dergilerini konu, yöntem ve meta-teoriler açısından, Kristensen ${ }^{10}$ ile Aydınlı ve Mathews ${ }^{11}$ disiplini merkezçevre açısından; Maliniak vd., ${ }^{12}$ Mitchell vd., ${ }^{13}$ Østby vd. ${ }^{14}$ ise disiplini cinsiyet dağılımı açısından

1 Dönüş Çiçek ve Nazmi Kozak, “Anatolia: Turizm Araştırmaları Dergisi’nde Yayımlanan Hakem Denetimli Makalelerin Bibliyometrik Profili”, Türk Kütüphaneciliği, Cilt 26, No 4, 2012, ss. 735-736.

2 V.P. Diodato, Dictionary of Bibliometrics, Binghamton, NY, The Hawthorne Press, 1994'ten aktaran Çiçek ve Kozak, Anatolia, s.736.

3 Ibid.

4 Ola Wæver, “The Sociology of a not so International Discipline: American and European Developments in International Relations”, International Organization, Cilt 52, No 4, 1998, s. 697.

5 Haydar Yalçın, "Millî Folklor Dergisinin Bibliyometrik Profili (2007-2009)", Millî Folklor, Cilt 22, No 85, 2010, s. 211; Wæver, The Sociology, s. 697.

6 Marijke Breuning, Joseph Bredehoft ve Eugene Walton, "Promise and Performance: An Evaluation of Journals in International Relations", International Studies Perspectives, Cilt 6, No 4, 2005, ss. 447-461.

7 Kjell Goldmann, "Im Westen Nichts Neues: Seven International Relations Journals in 1972 and 1992”, European Journal of International Relations, Cilt 1, No 2, 1995, ss. 245-258.

8 Daniel Maliniak, Amy Oakes, Susan Peterson ve Michael Tierney, "International Relations in the US Academy", International Studies Quarterly, Cilt 55, No 2, 2011, ss. 437-464.

9 Waever, The Sociology, ss. 687-727.

10 Peter Marcus Kristensen, “Dividing Discipline: Structures of Communication in International Relations”, International Studies Review, No 14, 2012, ss. 32-50; Peter Marcus Kristensen,"Revisiting the "American Social Science" Mapping the Geography of International Relations”, International Studies Perspectives, Cilt 16, No 3, 2015, ss. 246-269.

11 Ersel Aydinlı ve Julie Mathews, "Are the Core and Periphery Irreconcilable? The Curious World of Publishing in Contemporary International Relations", International Studies Perspectives, Cilt 1, No 3, 2000, ss. 289-303.

12 Daniel Maliniak, Amy Oakes, Susan Peterson ve Michael Tierney, “Women in International Relations”, Politics \& Gender, Cilt 4, No 1, 2008, ss. 122-144.

13 Sara Mclaughlin Mitchell, Samantha Lange ve Holly Brus, "Gendered Citation Patterns in International Relations Journals”, International Studies Perspectives, No 14, 2013, ss. 485-492.

14 Gudrun Østby, Håvard Strand, Ragnhild Nordås ve Nils P. Gleditsch, "Gender Gap or Gender Bias in Peace Research? Publication Patterns and Citation Rates for Journal of Peace Research, 1983-2008”, International Studies Perspectives, No 14, 2013, ss. 493-506. 
incelerken, Brill ${ }^{15}$ ile Russett ve Arnold ${ }^{16}$ dergilere atıf analizi yapmışlardır. Türkiye'de ise Uİ alanına özgü bibliyometrik araştırma tespit edilmemiştir. ${ }^{17}$

Alandaki dergilerin incelenmesinin önemi Wæver tarafından "[Uİ dergileri] disiplinin en doğrudan ölçütüdür” ${ }^{18}$ ifadesiyle vurgulanmıştır. Önde gelen dergilerin bibliyometrik analizi ile alanın yönelimleri ve disiplinin kendi içindeki organizasyonu anlaşılabilmektedir. ${ }^{19}$ Türkiye özelinde Uluslararası İlişkiler dergisi, alana münhasır bir dergi olması ve Social Sciences Citation Index'te (SSCI) taranması nedeniyle, Uİ araştırmaları için önemli bir bilimsel mecradır. Derginin bibliyometrik analizi ile Türkiye'de Uİ disiplininde çalışan akademisyenlerin işbirliği tercihlerini, konu ve teori seçimlerini, üniversite ve yazar üretkenliği ile bunların zaman içerisindeki değişimlerini Dergi kesitinde ortaya koymak mümkündür. Bu örneklem üzerinden disiplinin Türkiye'deki genel gelişimi hakkında, kişisel yorum ve görüşlerden arındırılmış net bir fikir elde edilebilir.

$\mathrm{Bu}$ amaçla Derginin 14 yıllık yayın hayatı, ilki SSCI'da taranmaya başlanmasından önceki dönem olmak üzere 4-5-5 yıllık üç döneme (2004-2007, 2008-2012, 2013-2017) ayrılmış, bu süreçte Dergide yayımlanan 56 sayıdaki 316 özgün makale ve yazarlarının bibliyometrik verileri incelemiştir. Makaleler hakkında, makalenin dili, araştırma türü, ilgili anabilim dalı, konusu ve ilişkili olduğu teoriler; yazarlar hakkında ise yazar sayısı, üretkenliği, unvanı, kurumu, cinsiyeti ve köken ülkesi hakkında veriler bibliyometrik analiz ile derlenerek dönemsel değişimleriyle birlikte yorumlanmıştır.

\section{Uluslararası İlişkiler Dergisinin Bibliyometrik Analizi}

Yayın hayatına 2004'te başlayan Uluslararası İlişkiler dergisi 2017 yılı sonu itibariyle 14 cilt içinde 56 sayıya ulaşmıştır. Haziran 2018 tarihi itibariyle Dergide, 6 öğretim üyesinden oluşan yayın kurulu, 1 genel yayın koordinatörü, 2 yayın koordinatörü, 2 yönetici editör, 6 yardımcı editör görev almaktadır. Derginin 22 kişilik danışma kurulunda, Türkiye'deki 7 farklı üniversiteden 13 ve 8 yabancı üniversiteden 9 akademisyen yer almaktadır. ${ }^{20}$

Dergi, Türkiye çıkışlı olarak Uİ disiplinine münhasır ${ }^{21}$ yayın yapan sayılı dergilerden olmasının yanı sıra, 2008'de SSCI'da taranmaya başlanmış, halen bu indekste taranan alana özgü tek Türkiye çıkışlı dergidir. Ayrıca Siyaset Bilimi ve Uİ alanlarında yayın yapan Türkiye çıkışlı dergiler arasında, halen, etki faktörü en yüksek 4 dergi arasındadır. ${ }^{22} 2014$ 'te Türkiye'deki Uİ akademisyenleri tarafından alandaki Türkiye çıkışlı en etkili yayın seçilen ${ }^{23}$ Dergi hakkında genel bilgiler Tablo 1'de gösterilmiştir.

15 Margaret S. Brill, "Government Publications as Bibliographic References in the Periodical Literature of International Relations: A Citation Analysis”, Government Information Quarterly, Cilt 7, No 4, 1990, ss. 427-439.

16 Bruce Russett ve Taylor Arnold, "Who Talks, and Who's Listening? Networks of International Security Studies”, Security Dialogue, Cilt 41, No 6, 2010, ss. 589-598.

17 Pınar Bilgin’in SBF Dergisi’ni güvenlik çalışmaları açısından değerlendirdiği "Uluslararası İlişkiler Çalışmalarında "Merkez-Çevre”: Türkiye Nerede?”, Uluslararası İlişkiler, Cilt 2, No 6, 2005, ss. 3-14 makalesi, matematiksel veya istatistiksel bir yöntem kullanılmadığı için bibliyometrik araştırma sınıfına girmemektedir.

18 Wæver, The Sociology, s. 697.

19 Kristensen, Dividing Discipline, s. 33.

20 Uluslararası İlişkiler Dergisi, Künye, http://www.uidergisi.com.tr (Erişim Tarihi 3 Haziran 2018).

21 Alandaki dergilerin çoğu, sadece Uİ alanında değil, genel olarak Siyaset Bilimi ve Uluslararası İlişkiler alanında yayın yapmaktadır.

22 Diğerleri Insight Turkey, Journal of Economic Cooperation and Development ve All Azimuth'dur. Scimago Journal \& Country Rank, https://www.scimagojr.com/journalrank.php?category=3320\&country=TR (Erişim tarihi: 03 Haziran 2018).

23 TRIP 2014 sonuçlarına göre, sırasıyla Uluslararası İlişkiler Dergisi (\%24), Perceptions (\%13), Insight Turkey (\%12) ve 
Tablo 1. Uİ Dergisi Hakkında Genel Bilgiler, 2004-2017

\begin{tabular}{lr}
\hline Toplam cilt sayısı & 14 \\
Toplam sayı & 56 \\
Toplam özel sayı & 11 \\
Özgün makale sayısı & 316 \\
Çeviri makale sayısı & 21 \\
Sayı başına düşen ortalama makale sayısı & 6 \\
Yayımlanan makalelerin toplam sayfa sayısı & 8300 \\
Bir makalenin ortalama sayfa uzunluğu & 26 \\
Toplam münferit yazar sayısı & 319 \\
Toplam anahtar kelime sayısı & 1507 \\
Makale başına düşen ortalama anahtar kelime sayısı & 5 \\
\hline
\end{tabular}

Derginin 2004-2017 arasında yayımlanan 56 sayısında; toplam 316 özgün makale, 21 çeviri makale, 88 kitap tanıtımı, 12 bibliyografya, 3 dizin, 1 açılış konuşması ve 8 toplantı tutanağı yer almıştır (Tablo 1). Araştırmada Dergide yayınlanan 316 özgün makale dikkate alındığında sayı başına düşen ortalama makale sayısı 5,6'dır (en az 1, en çok 10). Yayımlanan makalelerin toplam sayfa sayısı 8300, bir makalenin ortalama uzunluğu 26,2 sayfadır (en az 9, en çok 50). Dergiye katkıda bulunan yazar sayısı 319'dur. Makalelerde toplam 1507 anahtar kelime kullanılmıştır (en az 3, en çok 10) ve makale başına ortalama anahtar kelime sayısı 4,8'dir.

İncelenen tarih aralı̆̆ında Dergi 11 özel sayı yayımlamış, her özel sayı misafir editörlerce yayına hazırlanmıştır. İlk özel sayının çıkarıldığı 2006 yılından itibaren, hemen her yıl bir özel sayı; 2008 ve 2011 yıllarında ikişer özel sayı yayımlanmış, 2009, 2010 ve 2016 yıllarında ise yayımlanmamıştır. Özel sayıların konu ve misafir editörleri Tablo 2'de gösterilmiştir.

Tablo 2. Özel Sayıların Konu ve Editörleri

\begin{tabular}{lll}
\hline Yıl-Sayı & Konu & Misafir Editör \\
\hline 2006 Sayı 9 & Küreselleşme & E.Fuat KEYMAN \\
\hline 2007 Sayı 14 & Savaş & Necati POLAT \\
\hline \multirow{2}{*}{2008 Sayı 18 } & Güvenlik & $\begin{array}{l}\text { Hans Günter BRAUCH } \\
\text { Mustafa AYDIN } \\
\text { Úrsula Oswald SPRING }\end{array}$ \\
\hline 2008 Sayı 20 & Enerji & Mert BİLGİN \\
\hline 2011 Sayı 29 & Uluslararası İlişkilerde Temel Kavramları Yeniden & Pınar BİLGİN \\
\hline 2011 Sayı 32 & 11 Eylül'den 10 Yıl Sonra Terörizmi Tartışmak & Bahar RUMELILI \\
\hline 2012 Sayı 34 & Türkiye'nin Üyeliğinin 60. Yılında NATO: Değişim, & Andreas GOFAS \\
\hline 2013 Sayı 40 & NÄnüşüm, Süreklilik & Serhat GÜVENÇ \\
\hline 2014 Sayı 42 & Arap Baharı Sonrası Ortadoğu’nun Uluslararası İlişkileri & Özlem TÜR \\
\hline 2015 Sayı 46 & Uluslararası İlişkilerde Kuramsal Okumalar & $\begin{array}{l}\text { Mustafa AYDIN } \\
\text { Sinem AKGÜL AÇIKMEŞE }\end{array}$ \\
\hline 2017 Sayı 54 & Paris İklim Zirvesi ve Yansımaları & (-) \\
\hline
\end{tabular}

New Perspectives on Turkey (\%7) Türkiye'de yayın yapan en etkili dergiler seçilmiştir. Mustafa Aydın, Fulya Hisarlıoğlu ve Korhan Yazgan, “Türkiye’de Uluslararası İlişkiler Akademisyenleri ve Alana Yönelik Yaklaşımları Üzerine Bir İnceleme: TRIP 2014 Sonuçları”, Uluslararası İlişkiler, Cilt 12, No 48, 2015, s. 23. 
Özel sayılarda genellikle özgün makaleler yer almakla birlikte, 2008 tarihli Güvenlik özel sayısında 1 makale hariç tamamı (8 makale) çeviri metinlerden oluşmuştur. Bu çevirilerin bir kısmı Dergiye özel yazılan makaleler iken, bir kısmı da daha önce kitap bölümü olarak yayımlanmış çalışmaların Dergiye özel şekilde yenilenmiş hali veya Türkçeye aktarımı şeklindedir.

\section{Makaleler Hakkında Bulgular}

\section{Makalelerin Yıllara Göre Dağılımı}

Yayımlanan 316 makalenin yıllara ve dönemlere göre dağılımı Şekil l'de gösterilmiştir.

Şekil 1. Makalelerin Dönemlere Göre Dağılımı

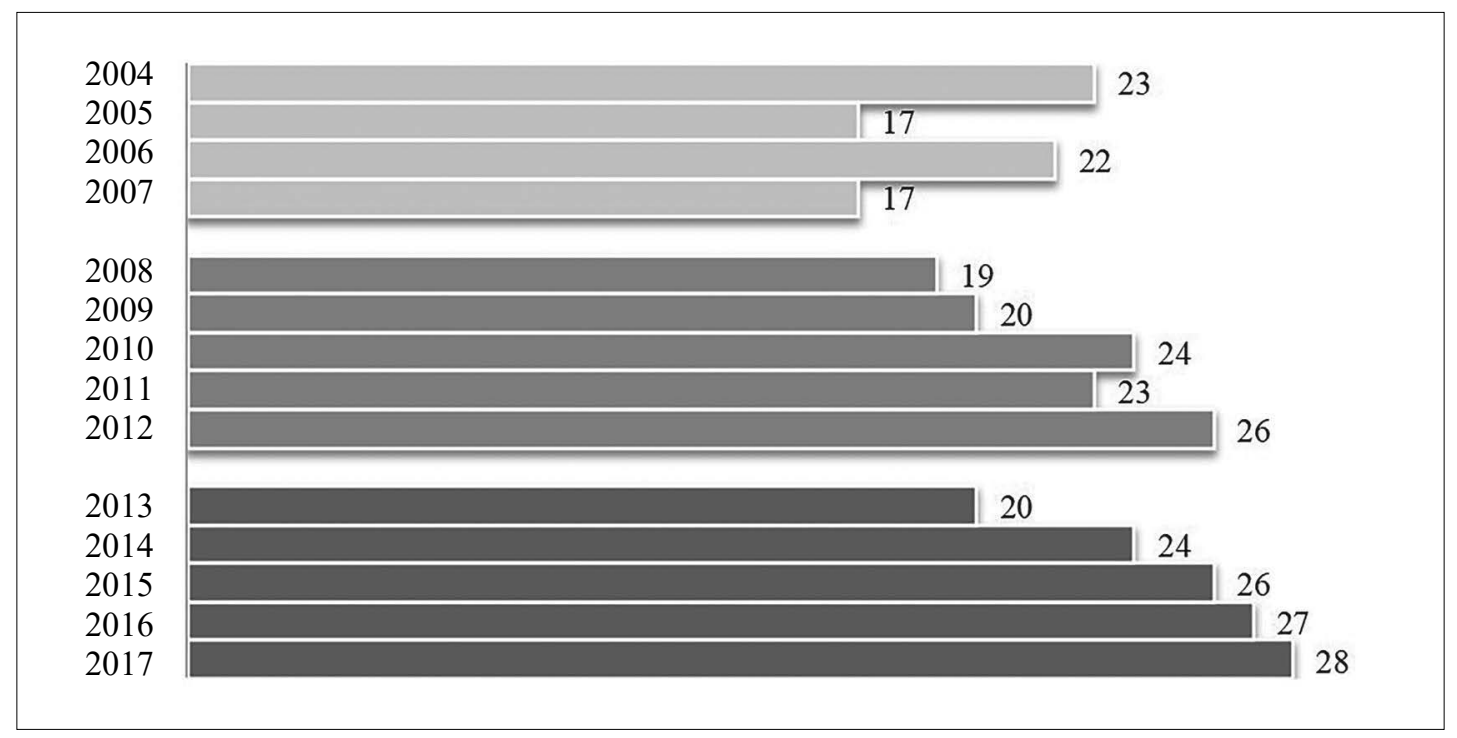

Şekil l'e göre, en az makale (17) 2005 ve 2007'de, en fazla makale (28) 2017'de yayımlanmıştır. I. dönemde 90, II. dönemde 115 ve III. dönemde ise 125 makale yayımlanmıştır. Bir yılda yayımlanan toplam makale sayısının ortalaması I. ve II. araştırma dönemlerinde 22,5 iken, III. dönemde 25 'e çıkmıştır. Derginin 2008 yılında SSCI'da taranmaya başlanmasıyla birlikte, bir sayıda yayımlanan ortalama makale sayısının da arttığı görülmektedir.

\section{Makalelerin Dillere Göre Dağılımı}

Uİ dergisi Türkçe ve İngilizce olmak üzere iki dilli bir yayındır. Çeviri makaleler hariç tutulduğunda, özgün makalelerin dil dağılımı Şekil 2'de gösterilmiştir. 
Şekil 2. Makalelerin Yayın Diline Göre Dağılımı

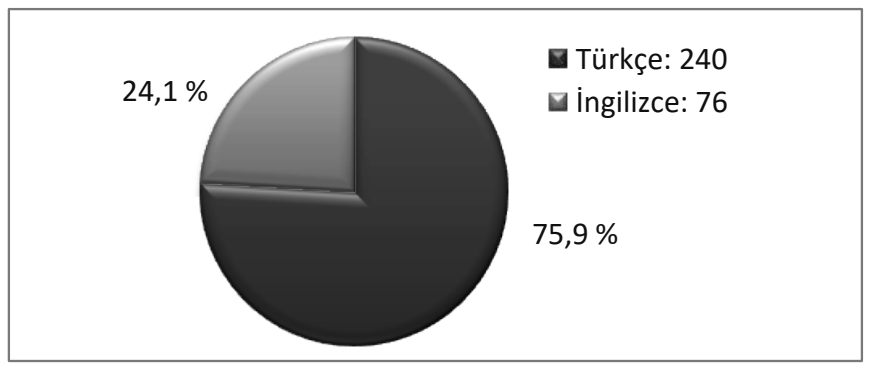

316 makalenin 240’1 $(\% 75,9)$ Türkçe, 76’sı $(\% 24,1)$ İngilizcedir. Makale dillerinin dönemsel dağılımı Tablo 3’te gösterilmiştir.

Tablo 3. Makale Yayın Dillerinin Dönemlere Göre Değişimi

\begin{tabular}{lcccccccc}
\hline & $\mathbf{2 0 0 4 - 2 0 0 7}$ & \multicolumn{2}{c}{$\mathbf{2 0 0 8 - 2 0 1 2}$} & \multicolumn{2}{c}{$\mathbf{2 0 1 3 - 2 0 1 7}$} & \multicolumn{2}{c}{$\mathbf{2 0 0 4 - 2 0 1 7}$} \\
& f & \% & f & \% & f & \% & f & \% \\
\hline Türkçe & 69 & 87,3 & 82 & 73,2 & 89 & 71,2 & 240 & 75,9 \\
İngilizce & 10 & 12,7 & 30 & 26,8 & 36 & 28,8 & 76 & 24,1 \\
\hline Toplam & $\mathbf{7 9}$ & $\mathbf{1 0 0}$ & $\mathbf{1 1 2}$ & $\mathbf{1 0 0}$ & $\mathbf{1 2 5}$ & $\mathbf{1 0 0}$ & $\mathbf{3 1 6}$ & $\mathbf{1 0 0}$ \\
\hline
\end{tabular}

Tablo 3’e göre, Derginin I. döneminde İngilizce makalelerin toplam makalelere oranı \%12,7 iken bu oran II. dönemde \%26,8, III. dönemde \%28,8 olmuştur. İngilizce makalelerin genel toplam içindeki payı \%24,1 olmakla birlikte, oransal olarak dönemler boyunca artmıştır. İngilizce makale yazarlarının kökenleri Tablo 4'te gösterilmiştir.

Tablo 4. İngilizce Makale Yazarlarının Kökenlerine Göre Dağılımı

\begin{tabular}{|c|c|c|c|c|}
\hline Köken & Çalıştığı Kurum & f & $\%$ & Toplam \\
\hline \multirow{2}{*}{ Türkiye Kökenli Yazar Sayısı } & Türkiye'de & 62 & 57 & \multirow{2}{*}{69} \\
\hline & Yurtdışında & 7 & 6 & \\
\hline \multirow{2}{*}{ Yabancı Yazar Sayısı } & Yurtdışında & 33 & 31 & \multirow{2}{*}{39} \\
\hline & Türkiye'de & 6 & 6 & \\
\hline Genel Toplam & & 108 & $\% 100$ & 108 \\
\hline
\end{tabular}

Tablo 4'e göre, 76 İngilizce makalenin 69'u Türkiye kökenli, 39'u yabancı olan toplam 108 yazar tarafından hazırlanmıştır. Bu yazarların 62'si (\%57) Türkiye'de, 7’si (\%6) yurtdışında bir kurumu adres gösteren Türkiye kökenli, 33'ü (\%31) yurtdışında ve 6’sı (\%6) Türkiye'de bir kurumu adres gösteren yabancı yazardır.

Dergide yayımlanan İngilizce makale sayısının az olmasının nedenleri, yazar kökenlerinin alanyazında yer alan bilgilerle birlikte düşünülmesiyle ortaya konabilir. Dünya genelinde sosyal bilimcilerin, fen bilimcilere kıyasla yabancı bir dilde yayın yapma oranlarının daha az olduğu ${ }^{24}$ ve

24 Diana Hicks, "The Difficulty of Achieving Full Coverage of International Social Science Literature and the Bibliometric Consequences”, Scientometrics, Cilt 44, No 2, 1999, s. 202. Hicks'e göre bu durum, sosyal bilimcilerin genel geçer bir 
sosyal bilimcilerin, hem üretici hem de okuyucu olarak konu ve dil seçimlerinde daha ulusal ${ }^{25}$ bir tavır takındıkları bildirilmektedir. ${ }^{26}$ İncelenen dönemde Dergide yayımlanan makalelerin sadece 1/4 ünün İngilizce olması bu durumu teyit eder niteliktedir. Buradan hareketle Uluslararası İlişkiler dergisi yazarlarının çoğunluğunun Türkçe yayın yapmayı tercih ettikleri söylenebilir. Diğer taraftan, Derginin ana amaçlarından biri "Türkiye'deki uluslararası ilişkiler literatürüne katkıda bulunmak ve bu konudaki boşluğu doldurmak" ${ }^{27}$ olarak belirtilmektedir. Nitekim bu amaçla, alanda ses getiren 21 İngilizce makale Türkçe’ye çevrilerek yayımlanmıştır. Bu nedenle daha fazla İngilizce makale yayımlamak Derginin özellikle tercih ettiği bir durum olarak görünmemektedir. Hatta Derginin Genel Yayın Yönetmeni Mustafa Aydın’ın, kendisiyle yapılan görüşmede belirttiği üzere, Dergi Yayın Kurulu, incelenen dönemin ilk yarısında yazarları, yayınlarını Türkçe göndermeleri konusunda cesaretlendirmiştir. ${ }^{28}$

\section{Makalelerin Araştırma Türlerine Göre Dağııımı}

Makalelerin araştırma türlerine karar verilirken, Aydınlı ve Mathews'un ${ }^{29}$ anahtar kelimeleri sınıflama ölçütleri temel alınmıştır. Bu sınıflandırmaya göre oluşan dağılım Şekil 3’te gösterilmiştir.

Şekil 3. Makalelerin Araştırma Türlerine Göre Dağılımı

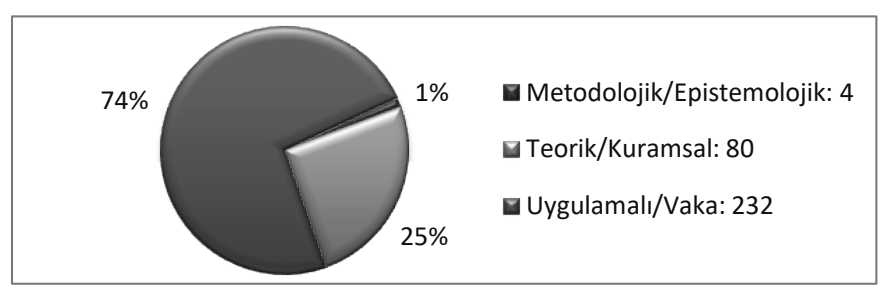

Şekil 3’e göre, 316 makalenin 232'si (\%73,4) uygulamalı/vaka analizi, 80’i (\%25,3) teorik/ kuramsal, 4 '’ü $(\% 1,3)$ metodolojik/epistemolojik çalışmalardır. Araştırma türlerinin dönemlere göre dağılımı Şekil 4’te gösterilmiştir.

terminolojiyi henüz oturtamamıs olmasından kaynaklanmaktadır. Bu iddiasını desteklemek için Hicks, yabancı dil olarak İngilizce'yi en iyi bilen milletlerden olan Norveç'te, fen bilimcilerinin \%80'inin İngilizce yayın yaparken, sosyal bilimcilerde bu sayının \%54'e düşmesini örnek olarak vermektedir (s. 202).

25 Örneğin uluslararası hukuk disiplininde yazılan makalelerin konuları büyük ölçüde yereldir ve Uİ alanındaki dergilerde yayımlanmaya uygun değildir. Benzer bir tespit herhangi bir fen bilimi alanı için yapılamaz. Ayrıca sosyal bilimlere içkin ideolojik/siyasi tercihler (gerek yazarlar gerekse editörler düzeyinde) sosyal bilim çalışmalarının uluslararasılaşması önünde önemli bir engeldir. Bu da fen bilimlerinde geçerli bir durum değildir. Sosyal bilimlerdeki bu genel durumun ötesinde, Kristensen, Uİ akademisyenlerini diğer bütün akademik disiplinlerden daha "vatanperver önyargılı ve ulusçu" ("patriotic biases" and "nationalistic") olarak tanımlamaktadır (Revisiting, s. 248).

26 Hicks, The Difficulty, s. 202; Kristensen, Revisiting, s. 248.

27 Uluslararası İlişkiler Dergisi, "Hakkımızda”, http://uidergisi.com.tr/hakkimizda (Erişim Tarihi 17 Aralık 2018).

28 Mustafa Aydın, İstanbul, 7 Ocak 2019, kişisel görüşme.

29 Aydınlı ve Mathews, The Core, s. 292. Buna göre, anahtar kelimesinde metodolojik anahtar kelimeler kullanan çalışmalar metodolojik, teorik terimler kullananlar teorik/kuramsal olarak değerlendirilmiş, fakat belli bir ülke, bölge ya da olayda bir teorinin uygulamasını yapan çalışmalar ise uygulamalı/vaka çalışması olarak sınıflandırılmıştır. Aynı şekilde politik ekonomi konusunu kuramsal olarak ele alan çalışmalar da teorik/kuramsal, belli bir ülke ya da bölgede politik ekonomi uygulamasını yapanlar uygulamalı/vaka çalışması olarak değerlendirilmiştir. 
Şekil 4. Araştırma Türlerinin Dönemlere Göre Dağılımı

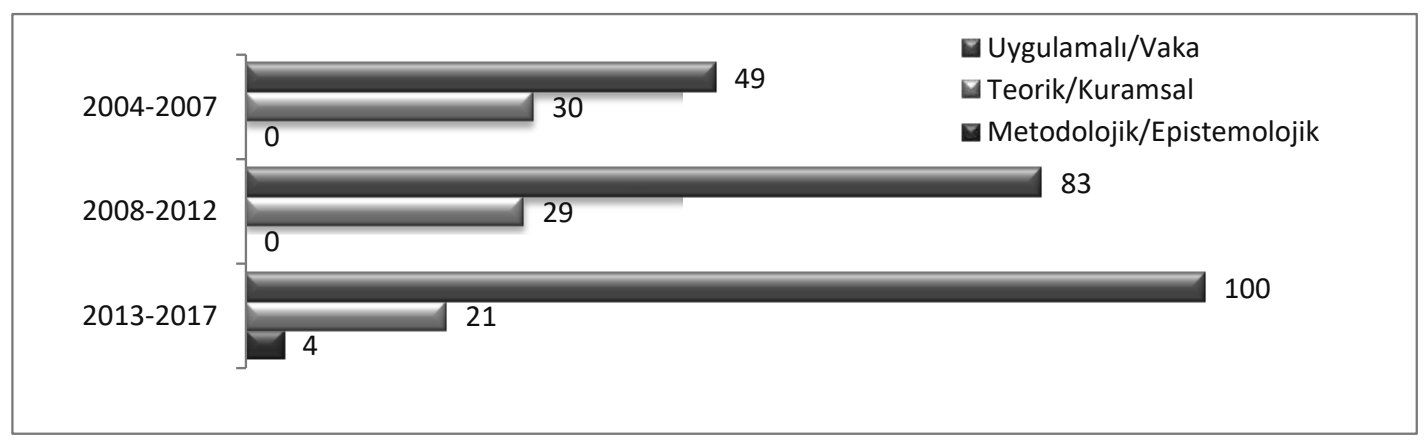

Dönemler karşılaştıııldığında, uygulamalı/vaka analizi çalışmalarının sayısı artarken, teorik/ kuramsal çalışmaların azaldığı görülmektedir. Bu veriler ışığında, Dergi kurucularının belirttiği ana amaçlardan olan Türkiyédeki kuramsal çalışmaların teşvik edilmesi hedefinin ${ }^{30}$ beklendiği ölçüde başarılı olamadığı söylenebilir. Diğer taraftan son dönemde metodolojik/epistemolojik araştırmaların Dergide yer almaya başlaması dikkat çekicidir.

\section{Makalelerin Ana Bilim Dallarına Göre Dağııımı}

Makalelerin Uİ içindeki beş temel ana bilim dalına dağılımının ${ }^{31}$ sonuçları Şekil 5 'te gösterilmiştir. Buna göre, 316 makalenin 242'si (\%76,6) Uluslararası İlişkiler ana bilim dalına aittir. 29 makale $(\% 9,2)$ ile ikinci sırada Avrupa Birliği, arkasından 24 makale $(\% 7,6)$ ile Uluslararası Hukuk gelmektedir. Uluslararası Politik Ekonomi ana bilim dalından toplamda $11(\% 3,4)$, Siyasi Tarih'ten ise $10(\% 3,2)$ makale yayımlanmıştır. Ana bilim dallarının dönemlere göre dağılımı Şekil 6’da gösterilmiştir.

Şekil 5. Makalelerin Ana Bilim Dallarına Göre Dağılımı

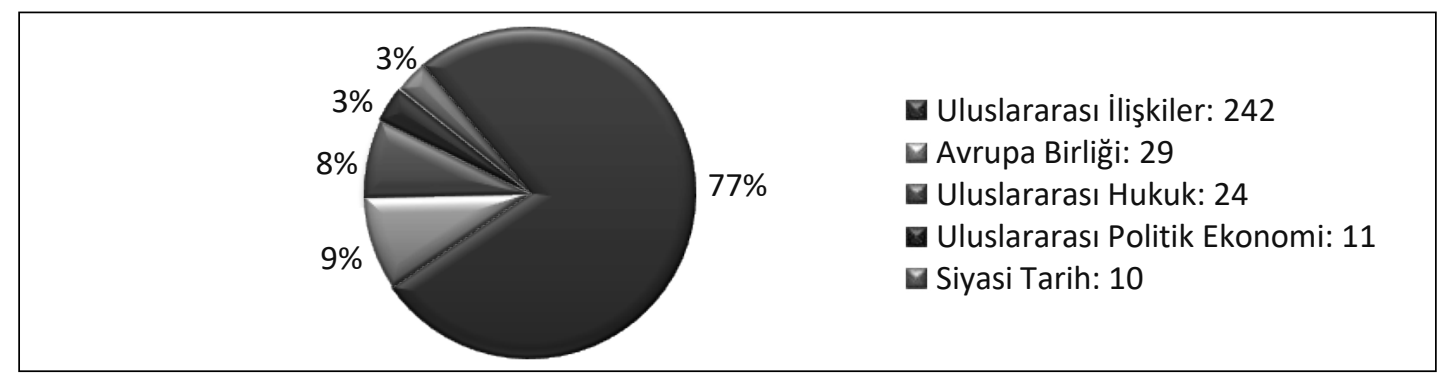

Buna göre, I. dönemde Siyasi Tarih ana bilim dalından hiç araştırma yokken, son iki dönemde az sayıda olsa da Dergide yer aldığı görülmektedir. İlk iki dönemde Uluslararası Politik Ekonomi sadece ikişer araştırmayla Dergide yer alırken, son dönemde 7 araştırma sayısına ulaşmıştır. Uluslararası

30 Mustafa Aydın, “Türkiye’de Uluslararası İlişkiler Çalışmaları ve Eğitimi Toplantı Tutanakları”, Türkiye'de Uluslararası İlişkiler Çalışmaları ve Eğitimi Paneli, 16-17 Nisan 2005, Uluslararası İlişkiler, Cilt 2, No 6, 2005, s. 25.

31 Teori, metodoloji ve dış politika konuları Uluslararası İlişkiler; anılar ve biyografiler, Osmanlı dönemi, erken cumhuriyet, Dünya Savaşları gibi konular Siyasi Tarih; uluslararası kamu ve özel hukuk, örgütler konuları Uluslararası Hukuk; $A B$ kurumları, hukuku ve politikaları Avrupa Birliği; uluslararası iktisat ve ticaret çalışmaları Uluslararası Politik Ekonomi ana bilim dalı olarak sınıflandırılmıştır. 
Hukuk ana bilim dalına ait araştırma sayısının yavaş bir şekilde arttı̆̆ı, Avrupa Birliği ana bilim dalına ait araştırmaların ise son dönemde azaldığı görülmektedir. Bu veriler, Uİ ana bilim dalı temel kalmaya devam ederken, ilgi alanlarının zamanla çeşitlendiğini göstermektedir.

Şekil 6. Ana Bilim Dallarının Dönemlere Göre Dağılımı

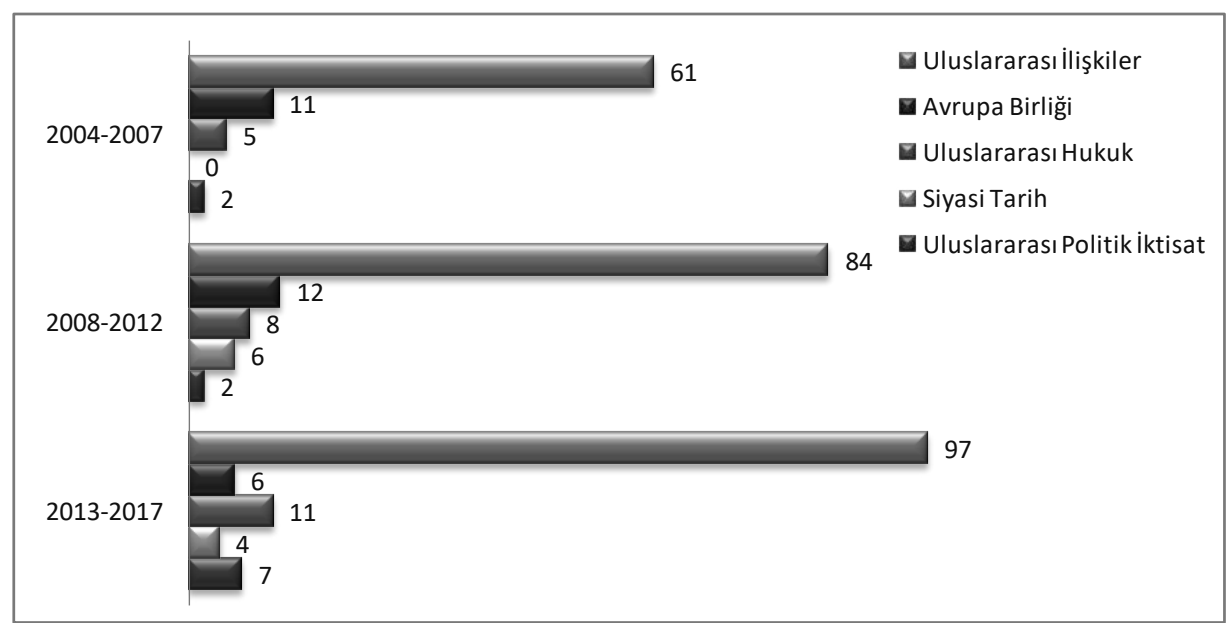

\section{Makalelerin Anahtar Kelimelere Göre Dağılımı}

Anahtar kelimelerin analizi, yazarların tercih ettikleri araştırma temalarının topluca görülmesini sağlar. Dergide en sık kullanılan anahtar kelimeler Şekil 7'de gösterilmiştir.

Şekil 7. Dergide En Çok Kullanılan Anahtar Kelimeler (2004-2017)

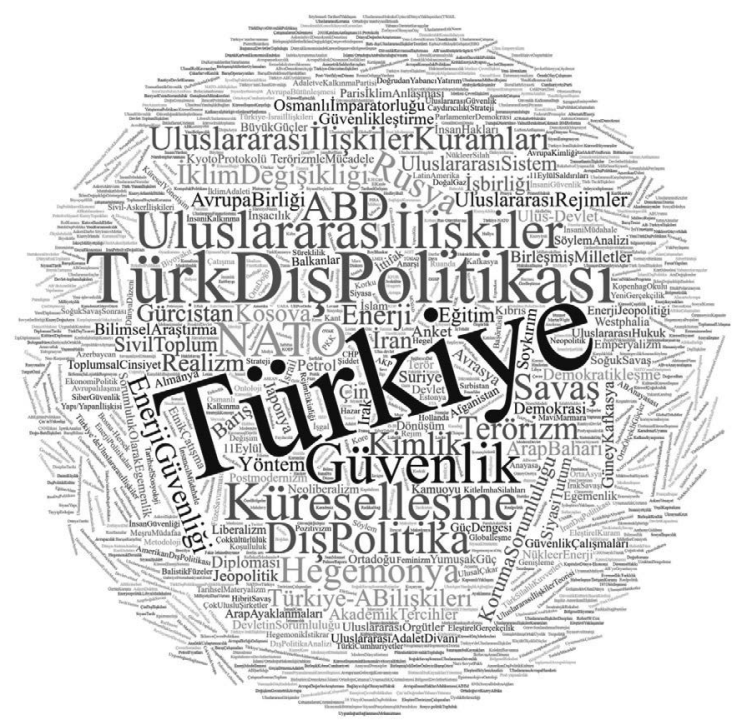

Şekil 7’ye göre, tüm sayılarda en sık tekrarlanan anahtar kelimeler Türkiye (34), Türk diş politikası (18), güvenlik (14), uluslararası ilişkiler (13), küreselleşme (13), NATO (12), dış politika 
(11) ve ABD (10)'dir. Kullanım sıklıkları, Dergide yayın yapan akademisyenlerin tema seçimlerinde ulusal ve yerel konulara meyilli olduklarını, ${ }^{32}$ kuramsaldan ziyade dış politika ağırlıklı çalıştıklarını, Amerikan merkezli Uİ disiplininin temel ilgi alanı olan güvenlik konusunun ${ }^{33}$ bir çevre ülke olan Türkiye'de de ana araştırma konusu kabul edildiğini göstermektedir. Hangi anahtar kelimelerin birlikte kullanıldığı araştırmalardaki bağlamların belirlenmesi açısından önemlidir. Bu amaçla, her dönem için bulut ve kümelenme analizleri yapılmıştır.

Şekil 8. 2004-2007 Dönemi Anahtar Kelimeler Bulutu ve Kümelenmesi
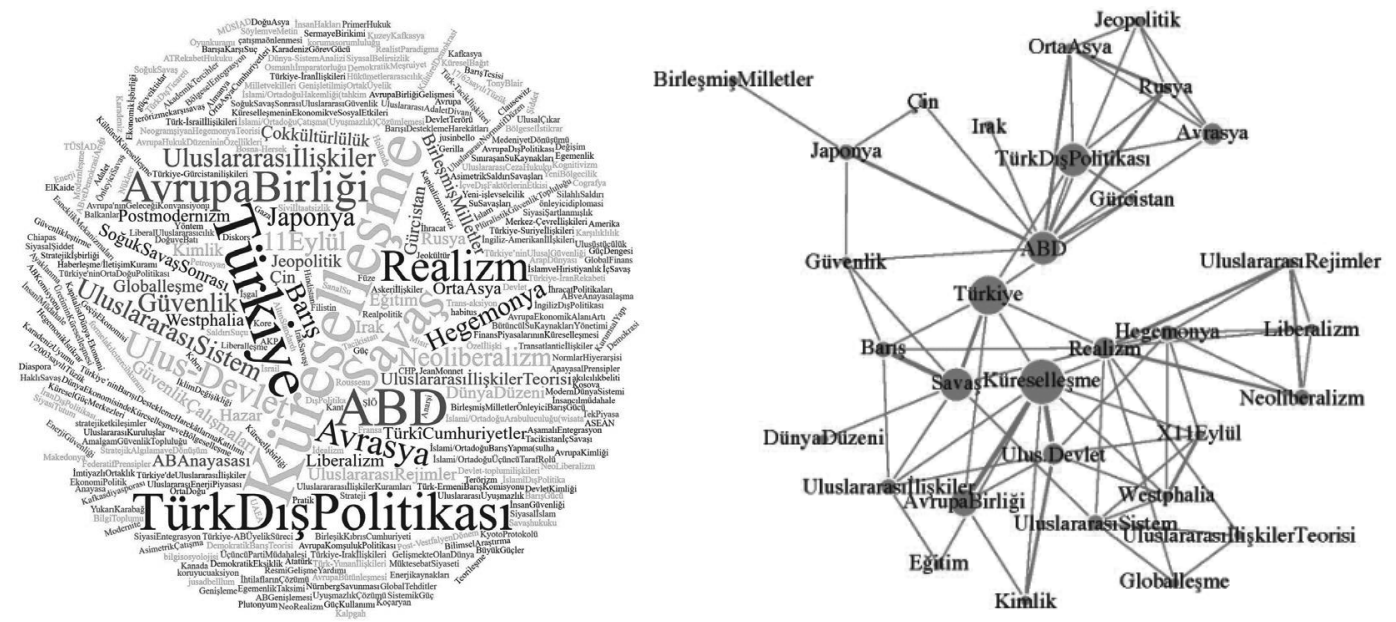

Şekil 8'de gösterildiği üzere, 2004-2007 döneminde 303 farklı anahtar kelime, toplam 383 defa kullanılmış, en sık kullanılan anahtar kelimeler küreselleşme (8), Türkiye (7), Türk dış politikası (6), savaş (6), $\mathrm{ABD}$ (6) ve $\mathrm{AB}$ (5) olmuştur. Bu dönemde yayımlanan özel sayıların konularının, dönemin anahtar kelimelerinin kullanım sıklığı üzerinde belirleyici olduğu gözlenmektedir. $\mathrm{Bu}$ çerçevede, dönemin özel sayılarının konuları olan "küreselleşme" ve "savaş" bu dönemin en çok kullanılan anahtar kelimeleri arasındadır. Anahtar kelimelerin kümelenme analizi incelendiğinde, küreselleşme en fazla $\mathrm{AB}$ ve ulus-devlet bağlamında ele alınmış, Türkiye ABD’nin yanı sıra komşu devletler ve komşu bölgelerle birlikte, Türk dış politikası ise $\mathrm{ABD}$, savaş, barış ve küreselleşme ekseninde incelenmiştir.

$32 \mathrm{Bu}$ durum Kristensen'in Uİ akademisyenlerinin konu seçimlerinde ulusal konulara eğilimli oldukları görüşüyle de örtüşmektedir (Revisiting, s. 248). Akademisyenleri ulusal konulara yönlendiren faktörlerden biri de merkez ülke akademisyenlerinin çevre ülke akademisyenlerinden, sadece kendi ülkeleri hakkında araştırmalar beklemeleridir. Bu durum Aydınlı ve Mathews'ın anonim olarak atıfta bulundukları “önde gelen bir Türk Uİ akademisyeninin”, yurt dışında sadece kendi ülkesi hakkındaki görüşlerine itibar edilmesinden şikayet etmesi örneğinde görülmektedir (The Core, s. 299).

33 Barry Buzan ve Lene Hansen, The Evolution Of International Security Studies, Cambridge UK, Cambridge University Press, 2009, s. 1; Russett ve Arnold, Who Talks, s. 589. 
Şekil 9. 2008-2012 Dönemi Anahtar Kelimeler Bulutu ve Kümelenmesi
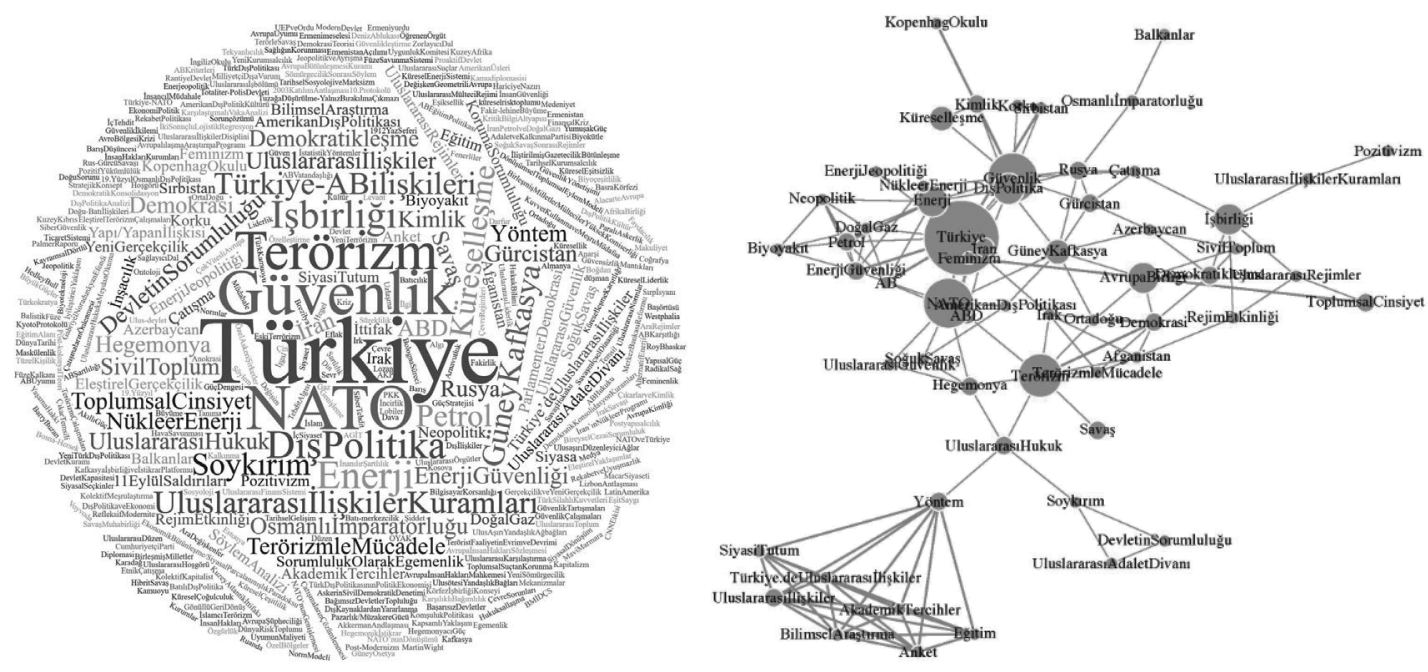

Şekil 9'da gösterilen 2008-2012 döneminde, 397 farklı anahtar kelime 533 kere kullanılmıştır. Bu dönemde en sık kullanılan anahtar kelimeler Türkiye (12), güvenlik (8) ve NATO (8), terörizm (7), dış politika (5), işbirliği (5) ve enerji (5) olmuştur. Dönem içinde yayımlanan "güvenlik", "enerji”, "terör” ve "NATO” özel sayılarının anahtar kelime kullanım sıklı̆ııı belirlediği görülmektedir. Bu dönemdeki anahtar kelime kümelenmeleri incelendiğinde, güvenlik ve dış politika konularının birlikte incelendiği, Orta Asya ve Kafkasya ülkelerinin ise enerji açısından ziyade, güvenlik bağlamında ele alındığı görülmektedir.

Şekil 10. 2013-2017 Dönemi Anahtar Kelimeler Bulutu ve Kümelenmesi
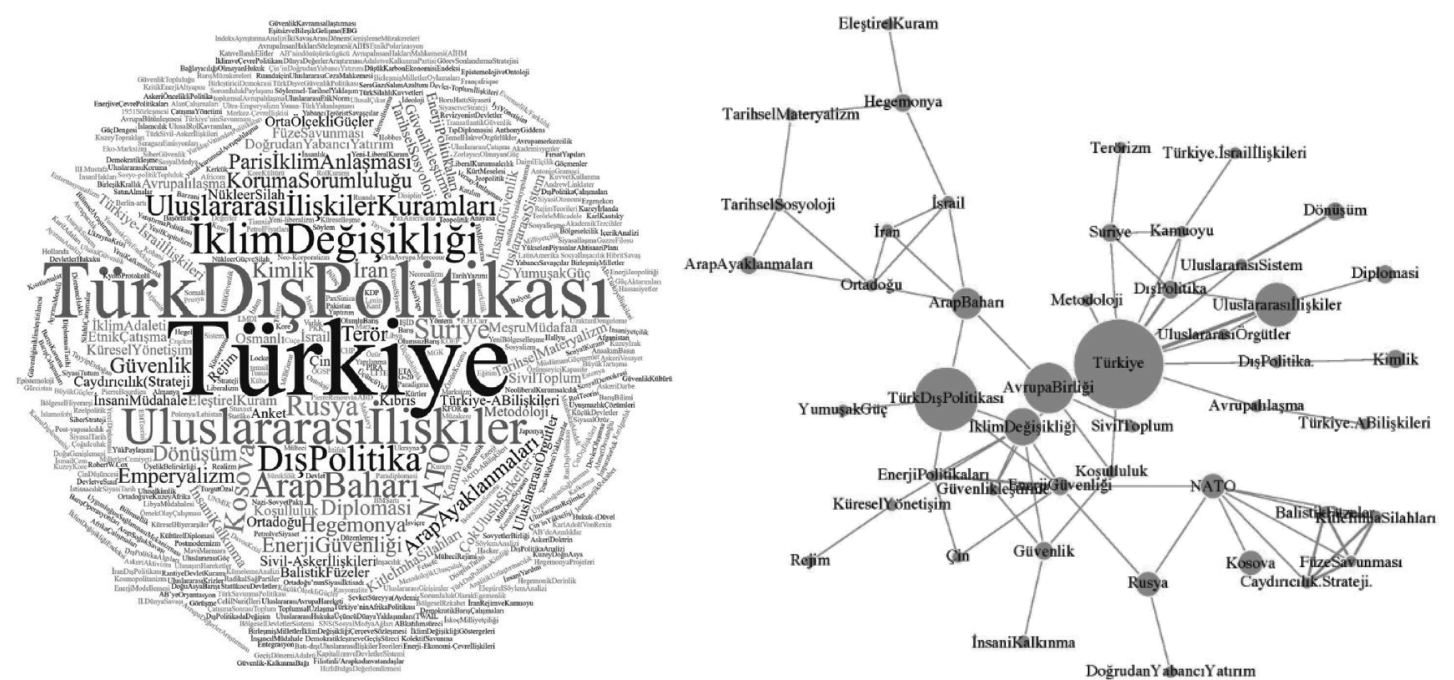

Şekil 10'da verilen 2013-2017 dönemine ait 471 anahtar kelime 591 kere kullanılmış, en sık kullanılanlar ise Türkiye (15), Türk dış politikası (11), uluslararası ilişkiler (7), iklim değişikliği 
(6), dış politika (5) ve Arap Baharı (5) olmuştur. Önceki dönemlere benzer şekilde, "NATO”, "Arap Baharı", "Paris İklim Zirvesi” ve "Uluslararası İlişkilerde Kuramsal Okumalar” özel sayıları dönemin anahtar kelimelerini belirlemiştir. III. dönemde anahtar kelime çeşitliliği artmış görünmektedir. $\mathrm{Bu}$ durum ana bilim dalları gibi araştırma temalarının da zamanla çeşitlendiği şeklinde yorumlanabilir. Dönemin kümelenme analizine bakıldığında, Türkiye'nin terörden metodolojiye farklı eksenlerde incelendiği, güvenlik konusuna, Türk dış politikası için enerji, NATO için ise silahlanma ve savunma bağlamında yoğunlaşıldığı görülmektedir.

\section{Makalelerin Konulara Göre Dağılımı}

Makale konularının analizi, alandaki akademisyenlerin odaklandığı konuları ortaya koyma potansiyeline sahiptir. Uİ dergisi yazarlarının konu seçimleri ${ }^{34}$ Şekil 11'de gösterilmiştir.

Şekil 11. Makalelerin Konularına Göre Dağılımı

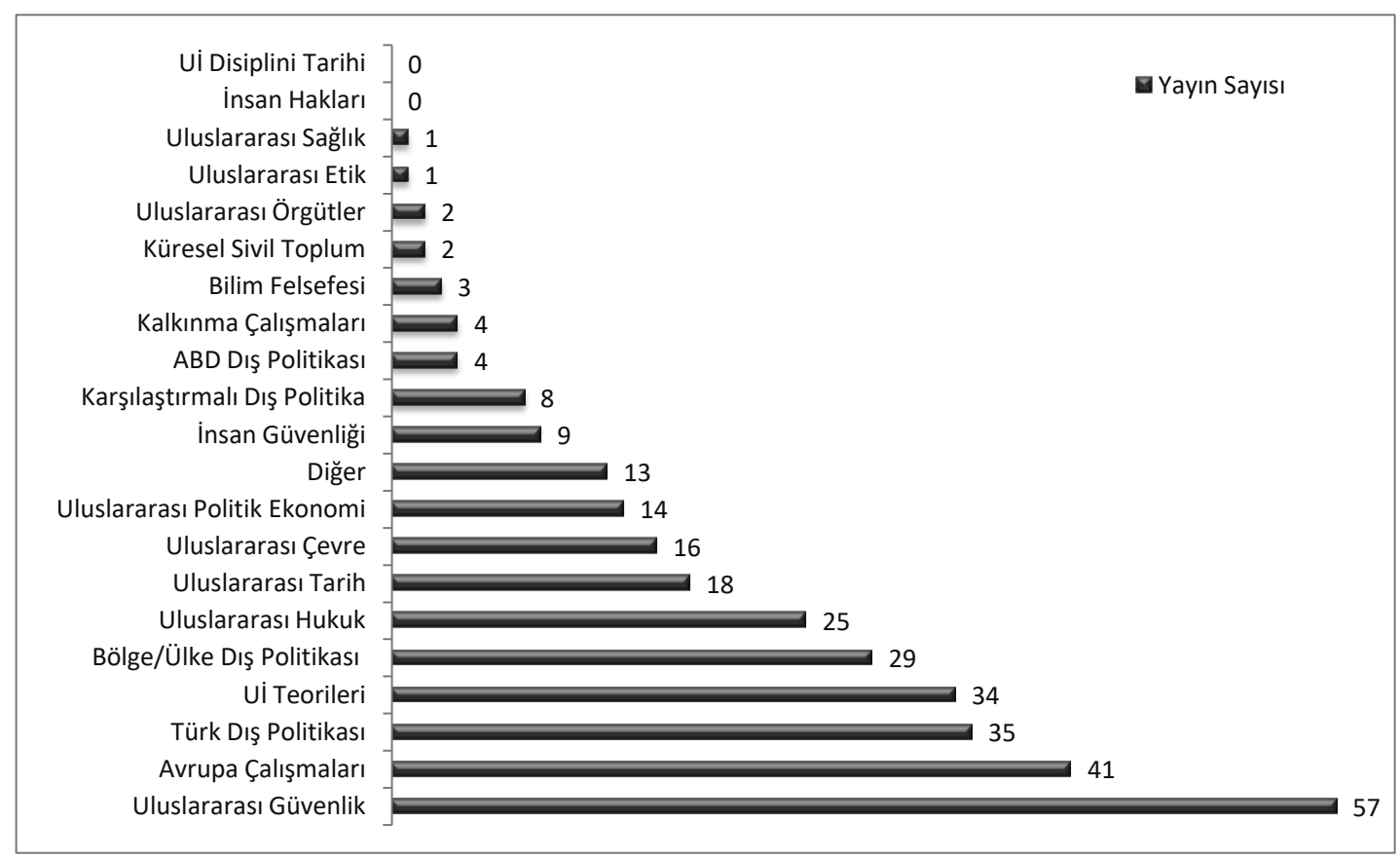

Makalelerde en çok ele alınan konular, uluslararası güvenlik ${ }^{35}$ (\%18), Avrupa çalışmaları (\%13) ve Türk dış politikası (\%11) olmuştur. Bu oranlar TRIP 2014 sonuçları ile kıyaslandığında dünya geneli ile uyumlu, Türkiye ile uyumsuz bir görünüm ortaya çıkmaktadır. Batı merkezli Uİ

34 Konuların belirlenmesinde TRIP çalışma konusu sorusundaki seçenekler temel alınmıştır. Bkz. TRIP, "Variables", https://trip.wm.edu/charts/\#/bargraph/43/6805 (Erişim Tarihi 19 Nisan 2018). Makalelerin konularının belirlenmesinde, Adnan Menderes, Ege ve Dokuz Eylül üniversitelerinden 10 kişilik Uİ akademisyen grubundan anahtar kelimelere bakarak, seçenekler arasından makale için en uygun konuyu belirlemeleri istenmiştir. İlgili makale için en çok seçilen konu, o makalenin araştırma konusu olarak belirlenmiştir.

35 Güvenlik konusunda 2008 ve 2013 'te çıkarılan iki özel sayı, anahtar kelimeler gibi çalışma konularının dağılımını da etkilemiş görünmektedir. 
çalışmalarının temel konusu olarak kabul edilen ${ }^{36}$ ve TRIP araştırmasında dünya genelinde \%17 ile ilk sırada yer alan uluslararası güvenlik, Dergide de en çok çalışılan konudur. Fakat Türkiye özelinde TRIP araştırması sonuçlarına göre bu konu \%14 ile üçüncü sırada yer almıştır. ${ }^{37}$ Dergide beşinci sıradaki bölge/ülke dış politikası (\%9) ve üçüncü sıradaki Türk dış politikası (\%11) konuları, TRIP Türkiye sonuçlarında \%16'lık oranlarla birinci sıradadır. ${ }^{38}$ Dünya genelinde ise bu konular sırasıyla \%8 ve \%9'luk oranlarla üçüncü ve beşinci sırada gelmektedir. ${ }^{39}$ Dergide güvenlik ve dış politika konularının ağırlığı, Batı merkezli Uİ disiplini ve TRIP araştırmasının dünya geneli sonuçları ile uyumludur. Bu tespit Pınar Bilgin’in, Batının konu ve kuramlarını yine Batının kavram ve hipotezleri üzerinden çalışmanın, kuramsal çalışmalara çevreden yapılabilecek katkıları ve elde edilecek faydayı sınırlayacağı görüşünü akla getirmektedir. ${ }^{40}$ Dolayısıyla makalelerin eski konulara ne yenilik getirdiği içerik analizleri ile ortaya konmalıdır.

Makale konuları Derginin Türkiye'deki kuram çalışmalarına katkıda bulunmak amacı ${ }^{41}$ açısından değerlendirildiğinde, kuram çalışmalarının \%10,8 ile dördüncü sırada yer alması, Derginin bahsi geçen amaca, en azından oransal olarak ulaşamadığı şeklinde yorumlanabilir. Kuramsal çalışmaların azlığı, Türkiye'de yeni bir kuram üretilememesinin nedenlerini sorgulamaya açmaktadır: Yeteri kadar kuramsal çalışma yapılmadığı için mi yeni bir yaklaşım üretilememektedir, yoksa yeni bir kuram üretilemeyeceği ya da mevcut kuramlara katkı sağlanamayacağı düşüncesiyle mi kuramlara mesafeli yaklaşılmaktadır? Dergide ele alınan konular arasında kuram çalışmalarının azlığı cevabın ilk soruda aranması gerektiğine işaret etmektedir. ${ }^{42}$

Uluslararası güvenlikten sonra "dünya çapındaki Uİ akademisyenlerinin en önemli temel araştırma konusu” ${ }^{\text {\$3 }}$ olarak gösterilen uluslararası politik ekonomi ise Dergide \%4,4'lük oranla dokuzuncu sırada yer almıştır. Bu oran TRIP genel sonuçlarıyla da örtüşmemektedir. Anlaşıldığı kadarıyla UI dergisi yazarları, küresel eğilimlere uygun şekilde uluslararası politik ekonomi değil, merkezin temel konusu olan güvenlik konusunu çalışmayı tercih etmektedirler.

Konuların dönemsel değişimleri incelendiğinde (Tablo 5) ise Uİ disiplini tarihi, insan hakları gibi konulara hiç değinilmemiş olduğu; kalkınma ve bilim felsefesi konularının son dönemde ele alınmaya başlandığı, küresel sivil toplum ve uluslararası örgütlere zaten az olan ilginin ise giderek kaybolduğu ve küresel Uİ camiasının gözde konusu olan uluslararası politik ekonomiye ilginin azaldığı, ancak dış politika analizlerinin her dönemde öncelikli çalışma konusu olduğu görülmektedir.

36 Buzan ve Hansen, The Evolution, s. 1; Russett ve Arnold, Who Talks, s. 589.

37 Aydın vd., TRIP 2014, ss. 9-10.

38 Ibid.

39 Ibid, s. 10.

40 Bilgin, Merkez-Çevre, ss. 4-5.

41 Aydın, Tutanaklar, s. 25.

42 Küresel Uİ dergilerinde en çok kuramsal yayın yapan çevre ülkelerden biri Çin, bölgelerden biri ise Latin Amerika'dır ve her ikisi de Uİ teorilerine çok farklı paradigmalarla katkıda bulunmaktadır. Çin’in Uİ teorilerine katkısına bibliyometrik bir bakış için bkz: Kristensen, Revisiting, ss. 265-266.

43 Leonard Seabrooke ve Kevin L. Young, “The Networks and Niches of International Political Economy”, Review of International Political Economy, Cilt 24, No 2, 2017, s. 37. 
Tablo 5. Makale Çalışma Konularının Dönemlere Göre Değişimi

\begin{tabular}{|c|c|c|c|c|c|c|c|c|}
\hline & \multicolumn{2}{|c|}{ 2004-2007 } & \multicolumn{2}{|c|}{$2008-2012$} & \multicolumn{2}{|c|}{ 2013-2017 } & \multicolumn{2}{|c|}{ 2004-2017 } \\
\hline & f & $\%$ & f & $\%$ & f & $\%$ & f & $\%$ \\
\hline Türk Dış Politikası & 9 & 11,4 & 7 & 6,2 & 19 & 15,2 & 35 & 11,1 \\
\hline Bölge/Ülke Dış Politikası & 9 & 11,4 & 8 & 7,1 & 12 & 9,6 & 29 & 9,2 \\
\hline ABD Dış Politikası & - & - & 4 & 3,6 & - & - & 4 & 1,3 \\
\hline Avrupa Çalışmaları & 13 & 16,4 & 15 & 13,4 & 13 & 10,4 & 41 & 13,0 \\
\hline Karşılaştırmalı Dış Politika & 2 & 2,5 & 3 & 2,7 & 3 & 2,4 & 8 & 2,5 \\
\hline Uluslararası Güvenlik & 10 & 12,7 & 28 & 25,0 & 19 & 15,2 & 57 & 18,0 \\
\hline Uİ Teorileri & 10 & 12,7 & 9 & 8,0 & 15 & 12,0 & 34 & 10,8 \\
\hline Uluslararası Politik Ekonomi & 7 & 8,9 & 4 & 3,6 & 3 & 2,4 & 14 & 4,4 \\
\hline Kalkınma Çalışmaları & - & - & 2 & 1,8 & 2 & 1,6 & 4 & 1,3 \\
\hline Küresel Sivil Toplum & 1 & 1,3 & 1 & 0,9 & - & - & 2 & 0,6 \\
\hline Uİ Disiplini Tarihi & - & - & - & - & - & - & - & - \\
\hline İnsan Hakları & - & - & - & - & - & - & - & - \\
\hline İnsan Güvenliği & 2 & 2,5 & 2 & 1,8 & 5 & 4,0 & 9 & 2,9 \\
\hline Uluslararası Çevre & 1 & 1,3 & 7 & 6,2 & 8 & 6,4 & 16 & 5,1 \\
\hline Uluslararası Etik & - & - & 1 & 0,9 & - & - & 1 & 0,3 \\
\hline Uluslararası Tarih & 4 & 5,0 & 6 & 5,4 & 8 & 6,4 & 18 & 5,7 \\
\hline Uluslararası Hukuk & 6 & 7,6 & 9 & 8,0 & 10 & 8,0 & 25 & 7,9 \\
\hline Uluslararası Örgütler & 1 & 1,3 & 1 & 0,9 & - & - & 2 & 0,6 \\
\hline Uluslararası Sağlık & - & - & 1 & 0,9 & - & - & 1 & 0,3 \\
\hline Bilim Felsefesi & - & - & - & - & 3 & 2,4 & 3 & 0,9 \\
\hline Diğer & 4 & 5,0 & 4 & 3,6 & 5 & 4,0 & 13 & 4,1 \\
\hline Toplam & 79 & 100 & 112 & 100 & 125 & 100 & 316 & 100 \\
\hline
\end{tabular}

\section{Makalelerin Teorilere Göre Dağılımı}

Teori çalışmaları, akademisyenlerin dünyayı hangi paradigmalardan algıladıklarını ve araştırmalarını hangi temeller üzerinde şekillendirdiklerini göstermeleri açısından önemlidir. ${ }^{44}$ Sadece anahtar kelimelere dayalı bir bibliyometrik analiz ile makalelerin ele aldığı teorik yaklaşımların eksiksiz olarak tespit edilebilmesi her zaman mümkün değildir. Özellikle kuramsal olmayan araştırmalarda, yazarlar araştırmalarını bir teorik yaklaşıma göre şekillendirmiş, fakat bunu anahtar kelimelerde belirtmemiş olabilmektedirler. ${ }^{45} \mathrm{Bu}$ nedenle Dergide yayımlanan makalelerin dayandığı kuramsal yaklaşımların net olarak tespiti ancak içerik analizi ile mümkündür. Fakat dergide yayımlanan makalelerin içerik analizlerinin yapılması bu araştırmanın kapsamı dışında kaldığından, sadece anahtar kelimeleri arasında teorik yaklaşımlara yer veren makaleler değerlendirmeye alınmısstır. Bu tür makalelerde ele alınan teoriler Şekil 12'de gösterilmiştir. ${ }^{46}$

44 Ayrıca, Wæver'e göre, Uİ disiplininde yıldız olmak için teori çalışılması şarttır. The Sociology, s. 718.

45 Hakemlere bu konudaki uyarıları için teşekkür ederim.

46 Makalelerin teorileri, belli bir teorinin adını doğrudan veren ya da paradigmanın belirleyici kavramlarını kullanarak belli bir teoriye atıfta bulunan anahtar kelimelere göre tespit edilmiştir. Analize dahil edilen teorilerin belirlenmesinde TRIP teori tercihi sorusundaki seçenekler temel alınmıştır (TRIP, Variables). 
Şekil 12. Makalelerin Teorilere Göre Dağılımı

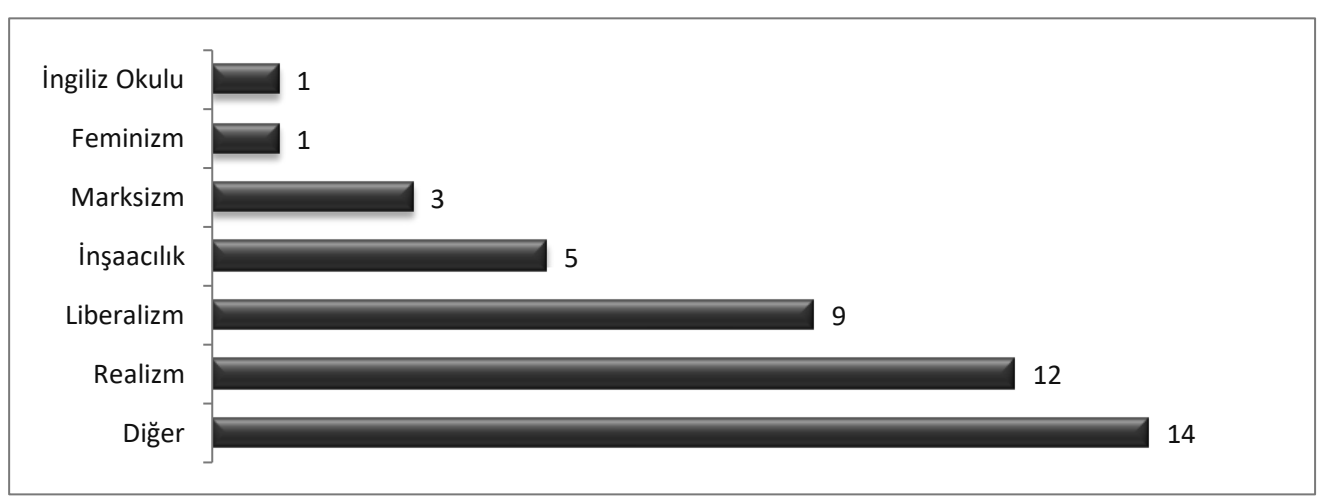

Dergide yayımlanan 316 makale içinde anahtar kelimelerinde herhangi bir teorik yaklaşıma yer veren makale sayısı 37'dir. Bunlardan altısında 2, birinde 3 teori birlikte ele alınmış, toplamda 45 kez bir teorik yaklaşımın adı anahtar kelimelerde geçmiştir. En çok ele alınan teoriler realizm (12) ve liberalizm (9) olmuştur. Birden fazla teorik yaklaşımın ele alındığı makalelerde, en çok "birinci büyük tartışmanın” tarafları realizm ve liberalizm ikilisi ele alınmıştır. TRIP 2014'te akademisyenler, dünya görüşleri olarak en çok realizm (\%32) ve inşacılık (\%28) teorilerini benimsediklerini söylemişlerse $\mathrm{de}^{47}$ bu durumun makalelerde ele alınan teorik yaklaşımlara yansımadığı görülmektedir. Teori çalışmalarının dönemsel dağılımı Tablo 6'da gösterilmiştir.

Tablo 6. Teori Çalışmalarının Dönemlere Göre Dağılımı

\begin{tabular}{lllllllll}
\hline & \multicolumn{2}{c}{$\mathbf{2 0 0 4 - 2 0 0 7}$} & \multicolumn{2}{c}{$\mathbf{2 0 0 8 - 2 0 1 2}$} & \multicolumn{2}{c}{$\mathbf{2 0 1 3 - 2 0 1 7}$} & \multicolumn{2}{c}{$\mathbf{2 0 0 4 - 2 0 1 7}$} \\
& f & \% & f & \% & F & \% & f & \% \\
\hline Realizm & 7 & 36,8 & 2 & 15,3 & 3 & 23,1 & 12 & 26,7 \\
Liberalizm & 6 & 31,6 & - & - & 3 & 23,1 & 9 & 20,0 \\
İnşacılık & - & - & 4 & 30,8 & 1 & 7,7 & 5 & 11,1 \\
İngiliz Okulu & - & - & 1 & 7,7 & - & - & 1 & 2,2 \\
Feminizm & - & - & 1 & 7,7 & - & - & 1 & 2,2 \\
Marksizm & - & - & 1 & 7,7 & 2 & 15,3 & 3 & 6,7 \\
Diğer & 6 & 31,6 & 4 & 30,8 & 4 & 30,8 & 14 & 31,1 \\
\hline Toplam & $\mathbf{1 9}$ & $\mathbf{1 0 0}$ & $\mathbf{1 3}$ & $\mathbf{1 0 0}$ & $\mathbf{1 3}$ & $\mathbf{1 0 0}$ & $\mathbf{4 5}$ & $\mathbf{1 0 0}$ \\
\hline
\end{tabular}

Tablo 6 incelendiğinde, derginin ilk döneminde ağırlıklı olarak kullanılan teorik yaklaşımlar realizm ve liberalizm iken, ilerleyen dönemlerde diğer kategorisinde toplanan eleştirel yaklaşım ve davranışsalcılık gibi alternatif paradigmalara daha fazla yer verildiği, en fazla teorik çeşitliliğin II. dönemde gerçekleştiği, son dönemde ise marksist teori çalışmalarının arttığı görülmektedir. Dergide ana akım teoriler ağırlığını korumaya devam ederken, radikal olarak değerlendirilen marksist teori çalışmalarının sayısı artmıştır. TRIP verileri ile Dergi sonuçları arasındaki uyumsuzluk, akademisyenlerin benimsedikleri ve dünya görüşlerini şekillendiren teorileri her zaman makalelerine yansıtmadıklarını düşündürmektedir. $\mathrm{Bu}$ durumun arka planında diğer teorilere yönelik eleştirel çalışmalar yapmak ya da çalışmaların yayınlanmasını kolaylaştırmak gibi farklı düşünceler olabilir.

47 Aydın vd., TRIP 2014, s. 14. 


\section{Makale Konularının Coğrafi Dağııımı}

Makalelerin ele aldığı coğrafi alanlar, akademisyenlerin ne kadar geniş bir alanla ilgilendiklerinin anlaşılması açısından incelenerek sonuçlar Şekil 13'te gösterilmiştir.

Şekil 13. Araştırma Konularının Bölgelere Göre Dağılımı

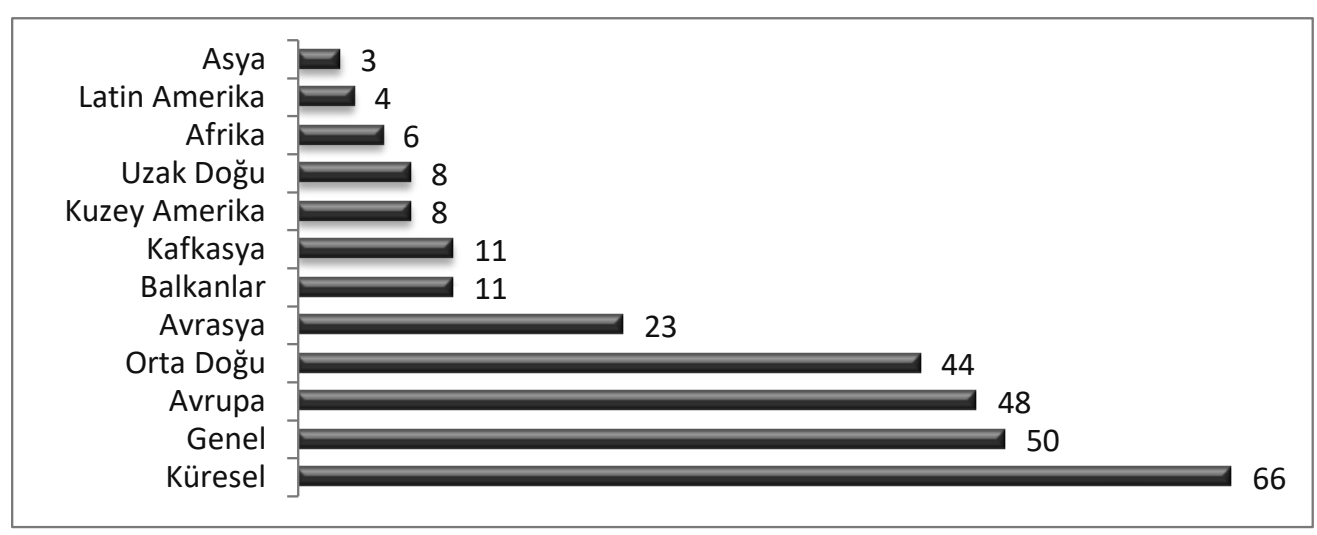

Buna göre, 316 makaleden 116'sı coğrafyayla sınırlanamayan teoriler ve ulus-devlet gibi genel konular (50) ile çevre, silahlanma ya da insan hakları gibi küresel konular (66) hakkında iken, coğrafi bir bölge hakkındaki makale sayısı 200'dür. ${ }^{48}$ Gerek kendi dinamikleri içinde, gerekse Türkiye ile birlikte en çok konu edilen bölgeler sırasıyla Avrupa (48), Orta Doğu (44) ve Avrasya (23)'dır. Tablo 7 'de bölgelerin dönemsel dağılımı gösterilmiştir. ${ }^{49}$

Tablo 7. Bölge Çalışmalarının Dönemlere Göre Dağılımı

\begin{tabular}{|c|c|c|c|c|c|c|c|c|}
\hline & \multicolumn{2}{|c|}{ 2004-2007 } & \multicolumn{2}{|c|}{ 2008-2012 } & \multicolumn{2}{|c|}{ 2013-2017 } & \multicolumn{2}{|c|}{ 2004-2017 } \\
\hline & f & $\%$ & f & $\%$ & f & $\%$ & f & $\%$ \\
\hline Afrika & - & - & 2 & 1,9 & 4 & 3,5 & 6 & 2,1 \\
\hline Asya & 3 & 3,9 & - & - & - & - & 3 & 1,1 \\
\hline Avrasya & 8 & 10,4 & 6 & 5,5 & 9 & 8,0 & 23 & 8,2 \\
\hline Avrupa & 14 & 18,2 & 18 & 16,7 & 16 & 14,2 & 48 & 17,0 \\
\hline Balkanlar & 2 & 2,6 & 6 & 5,5 & 3 & 2,7 & 11 & 3,9 \\
\hline Kafkasya & 3 & 3,9 & 8 & 7,4 & - & - & 11 & 3,9 \\
\hline K. Amerika & 4 & 5,2 & 3 & 2,8 & 1 & 0,9 & 8 & 2,8 \\
\hline L. Amerika & - & - & 2 & 1,9 & 2 & 1,8 & 4 & 1,4 \\
\hline Orta Doğu & 8 & 10,4 & 11 & 10,2 & 25 & 22,1 & 44 & 15,6 \\
\hline Uzak Doğu & 2 & 2,6 & 1 & 0,9 & 5 & 4,3 & 8 & 2,8 \\
\hline Küresel & 12 & 15,6 & 39 & 36,1 & 31 & 27,5 & 66 & 23,4 \\
\hline Genel & 21 & 27,2 & 12 & 11,1 & 17 & 15,0 & 50 & 17,8 \\
\hline Toplam & 77 & 100 & 108 & 100 & 113 & 100 & 282 & 100 \\
\hline
\end{tabular}

Tablo 7'de, küresel ve genel konulu makaleler hariç tutulduğunda, I. ve II. dönemlerde Avrupa çalışmalarının oransal olarak ilk sırada geldiği, III. dönemde ise Orta Doğu konulu araştırmaların ilk sırayı aldığı görülmektedir. Bu artışta 2010'dan itibaren gündeme gelen Arap Baharı’nın yansımaları ve 2014’te bu konuda çıkan özel sayının etkili olduğu anlaşılmaktadır. Avrupa çalışmaları azalırken Orta

48 Anahtar kelimelerde belli bir coğrafi alan, ülke ya da o bölgeyle özdeşlemiş bir kavram kullanılmışsa, bölge çalışması olarak kabul edilmiştir.

49 Birden fazla bölgeyi konu edinen makaleler sebebiyle toplam sayı (282), makale sayısından (200) fazla çıkmaktadır. 
Doğu coğrafyasına ilginin artması, özellikle dış politika çalışan akademisyenlerin güncel konulara ilgisiyle açıllanabilmektedir.

Coğrafi bölge üzerine olan 200 makalenin 143'ünde tek bir bölge, 57'sinde ise en az iki bölge birlikte ya da karşılaştırmalı olarak incelenmiştir. Bunların 50'sinde taraflardan biri Türkiye'dir. ${ }^{50}$ Türkiye'nin hangi bölgelerle birlikte incelendiği Tablo 8'de gösterilmiştir. ${ }^{51}$

Tablo 8. Türkiye İle Birlikte İncelenen Bölgeler

\begin{tabular}{lc}
\hline Bölgeler & f \\
\hline Avrupa-Türkiye & 19 \\
Orta Doğu-Türkiye & 15 \\
Kafkasya-Türkiye & 4 \\
Afrika-Türkiye & 3 \\
Avrasya-Türkiye & 3 \\
Balkanlar-Türkiye & 3 \\
Uzak Doğu-Türkiye & 3 \\
Asya-Türkiye & 1 \\
Kuzey Amerika-Türkiye & 1 \\
Latin Amerika-Türkiye & 0 \\
Toplam & $\mathbf{5 2}$ \\
\hline
\end{tabular}

Buna göre, Türkiye’nin en çok birlikte ele alındığı coğrafi bölgeler Avrupa, Orta Doğu ve Orta Asya’dır. Yazarların Türkiye’yi, örneğin Pasifik veya Latin Amerika gibi uzak coğrafyalarla birlikte incelemeyi tercih etmedikleri görülmektedir. Bölgesel çalışmaların ülkesel dağılımı Tablo 9'da gösterilmiştir.

Tablo 9. Makalelerin Ülkelere Göre Dağılımı

\begin{tabular}{lc}
\hline Ülke & f \\
\hline Türkiye & 93 \\
ABD & 13 \\
İran & 11 \\
İsrail & 8 \\
Rusya & 8 \\
Çin & 7 \\
Irak & 6 \\
Kosova & 6 \\
Gürcistan & 5 \\
Kibris & 5 \\
Japonya & 4 \\
Suriye & 4 \\
Afganistan & 3 \\
Ermenistan & 3 \\
Diğer (31) & 43 \\
\hline Toplam (45 ülke) & $\mathbf{2 1 9}$ \\
\hline
\end{tabular}

50 Anahtar kelimelerde Türkiye'ye yer verilmeyen diğer 7 makalede birlikte ele alınan bölgeler şu şekildedir: Kuzey Amerika-Orta Doğu (2), Kuzey Amerika-Asya (1), Kuzey Amerika-Uzak Doğu (1), Kuzey Amerika-Avrupa (1), Avrupa-Kafkasya (1) ve Avrupa-Orta Doğu (1).

51 İki makalede 3 bölge birlikte incelendiği için toplam bölge sayısı (52), toplam makale sayısından (50) fazla çıkmaktadır. 
Buna göre, 160 farklı makalede 45 farklı ülke tek başlarına ya da başka ülkelerle, toplam 219 defa ele alınmıştır. 93 makalenin 65 'inde Türkiye tek başına çalışma konusu iken, 28'inde başka ülkelerle incelenmiştir. Türkiye’nin birlikte ele alındığı ülkeler İsrail (5), İran (4), ABD ve Irak (3), BosnaHersek, Ermenistan, Kıbrıs, Sırbistan, Yunanistan ve Suriye (2), Almanya, Çin, Gürcistan, Kore, Kosova, Rusya, Somali, Tacikistan ve Tayvan (1) olmuştur. ${ }^{52} \mathrm{Bu}$ durum akademisyenlerin ulusal bir tutumla Türkiye bazlı araştırmalar yaptığını ve Türkiye'nin en çok komşu ülkeler ve yakın coğrafyası ile birlikte incelendiğini göstermektedir.

\section{Yazarlar Hakkında Bulgular}

Yazar sayıları çoklu sayım ve kesirli sayım olmak üzere iki farklı yöntemle hesaplanmıştır. Çok yazarlı makalelerdeki tüm yazarların hesaplandığı çoklu sayım yöntemine göre 316 makale 404 yazar tarafından hazırlanmışken, birden fazla yayında adı geçen yazarların sadece bir kere sayıldığı kesirli sayım yöntemine göre 319 münferit yazar Dergiye katkı sağlamıştır.

\section{Yazar Sayılarının Dağılımı}

Yazar sayılarının dağılımı Şekil 14’te gösterilmiştir.

Şekil 14. Yazar Sayılarına Göre Makalelerin Dağılımı

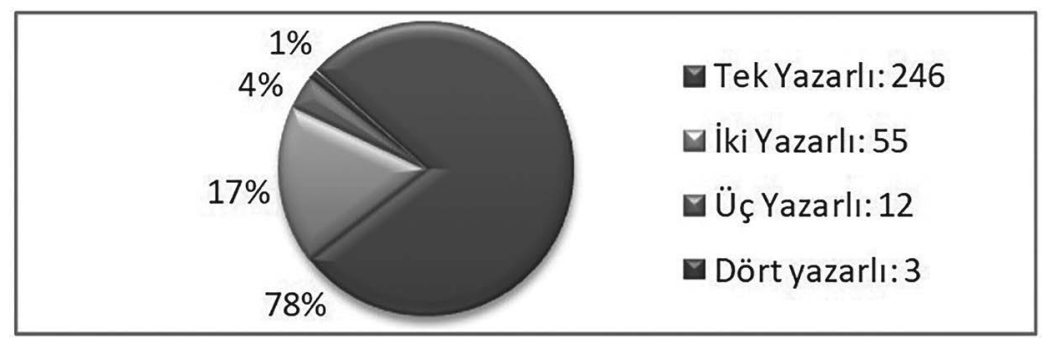

316 makalenin, 246'sının $(\% 77,9)$ tek yazarı, 70'inin $(\% 22,1)$ ise birden fazla yazarı vardır. 55’i $(\% 17,4)$ iki yazar, 12'si $(\% 3,8)$ üç yazar, 3’ü ise $(\% 0,9)$ dört yazar tarafından kaleme alınmıştır. Makale başına yazar sayısı 1,27'dir. Yazar sayılarının dönemsel dağılımı Tablo 10’da gösterilmektedir.

Tablo 10. Yazar Sayılarının Dönemlere Göre Dağılımı

\begin{tabular}{|c|c|c|c|c|c|c|c|c|}
\hline & \multicolumn{2}{|c|}{ 2004-2007 } & \multicolumn{2}{|c|}{$2008-2012$} & \multicolumn{2}{|c|}{ 2013-2017 } & \multicolumn{2}{|c|}{ 2004-2017 } \\
\hline & f & $\%$ & f & $\%$ & f & $\%$ & f & $\%$ \\
\hline 1 yazarlı & 74 & 93,6 & 83 & 74,1 & 89 & 71,2 & 246 & 77,9 \\
\hline 2 yazarlı & 5 & 6,4 & 23 & 20,5 & 27 & 21,6 & 55 & 17,4 \\
\hline 3 yazarlı & - & - & 6 & 5,4 & 6 & 4,8 & 12 & 3,8 \\
\hline 4 yazarlı & - & - & - & - & 3 & 2,4 & 3 & 0,9 \\
\hline Toplam & 79 & 100 & 112 & 100 & 125 & 100 & 316 & 100 \\
\hline
\end{tabular}

52 Üç ve daha fazla ülkenin birlikte incelendiği 7 makale sebebiyle toplam sayı makale sayısından fazla çıkmaktadır. 
Derginin I. döneminde çokyazarlı makalelerin toplam makalelere oranı \%6,4 iken, II. döneminde bu oran \%26'ya, III. döneminde ise $\% 28,8^{\prime}$ 'e yükselmiştir. Dünya genelinde Uİ alanında ortak yazarlı çalışma sayısının artışına ${ }^{53}$ paralel olarak çok yazarlı makale sayısının Dergide de giderek arttığı ancak çok benimsenmediği, işbirliğiyle yürütülen çalışmalarda üç yazardan büyük çalışma gruplarının az tercih edildiği, ortak yazarlığın iki kişiyle sınırlandırıldığı görülmektedir. Çok yazarlılıkta işbirliğinin nasıl gerçekleştiği Şekil 15 'te gösterilmiştir. ${ }^{54}$

Şekil 15. Çok Yazarlılığın Kökenlere Göre Dağılımı

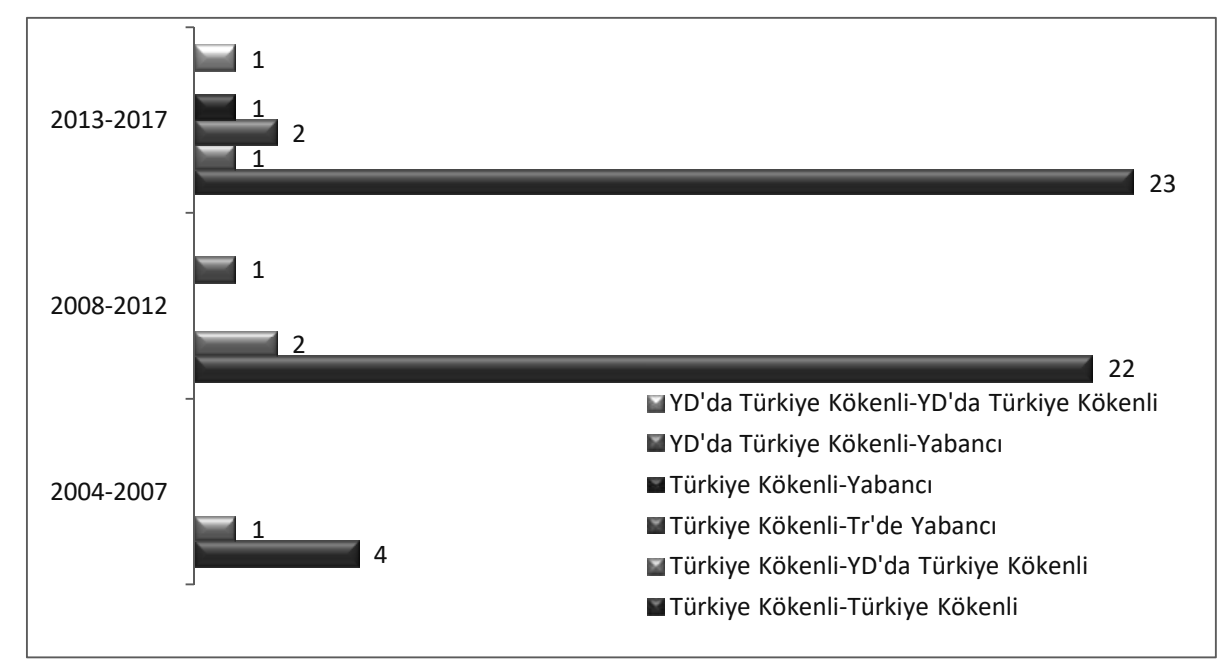

Şekil 15'te görüldüğü üzere, çok yazarlı makalelerde işbirliği büyük ölçüde Türkiye kökenli yazarlar arasında gerçekleşmektedir. Uluslararası işbirliği boyutu olan yayın sayısı zaman içerisinde artıyor görünmekle birlikte, son derece azdır. Türkiye kökenli-yabancı işbirliğinde yazılan makale sayısı 1'dir. ${ }^{55} \mathrm{Bu}$ sonuçlarla, Dergi akademisyenlerinin uluslararasılaşmada geri kaldığı, bilimsel işbirliği yapmak için kendi ülkelerinden akademisyenleri tercih ettikleri ortaya çıkmaktadır.

\section{Yazar Kökenleri}

Dergiye katkıda bulunan yazarların kökenleri Şekil 16'da gösterilmiştir. Buna göre, 404 yazarın 360' (\%89,2) Türkiye kökenli ve 44’ü (\%11) yabancı uyrukludur. Türkiye kökenli yazarların 342'si (\%84,7) Türkiye'de, 18'i $(\% 4,5)$ yurt dışında bir kurumu adres göstermiştir. Yabancı uyruklu 44 yazarın ise 37 'si $(\% 9,1)$ yurt dışında, 7’si $(\% 1,7)$ Türkiye’de bir kurumu adres göstermiştir. Yazar kökenlerinin dönemsel değişimi Tablo 11'de gösterilmiştir.

53 Breuning vd., Promise, s. 459.

54 Şekil 15 hazırlanırken, Türkiye'den bir kurumu adres göstermiş Türkçe isme sahip yazarlar Türkiye kökenli, Türkçe isme sahip fakat Türkiye dışındaki bir kurumu adres gösterenler Yurtdışında Türkiye kökenli Yazar olarak değerlendirilmiştir. Türkiye'de bir kurumu adres gösteren yabancı isimli yazarlar Türkiye'de Yabancı Yazar, yabancı ülkede bir kurumu adres göstermiş yabancı isimli yazarlar ise Yabancı Yazar olarak değerlendirilmiş, kurumlarının bulunduğu ülke yazarın köken ülkesi olarak kabul edilmiştir.

55 İstanbul Gelişim Üniversitesi’nden Dr. Öğr. Üyesi Emine Akçadağ ve Westphalian Wilhelms University Münster’den Dr. Elnur İsmayilov'un “Ukrayna Krizinin Rusya ve Japonya Arasındaki Kuril Adaları Sorununa Etkisi”, Uluslararası İlişkiler, Cilt 12, No 48, 2016, ss. 95-115 makaleleri. 
Şekil 16. Yazarların Kökenlerine Göre Dağılımı

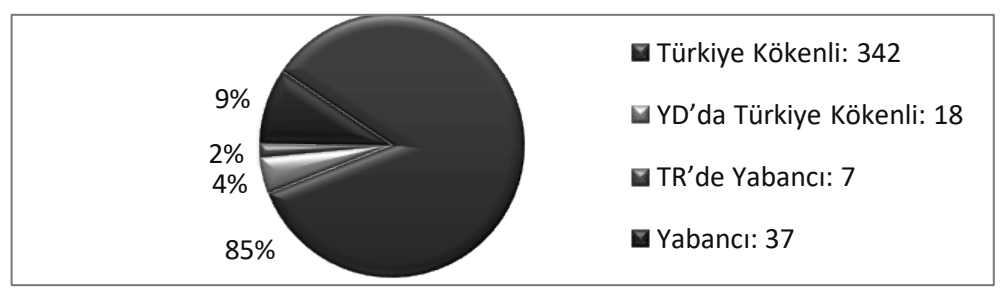

Tablo 11. Yazar Kökenlerinin Dönemsel Dağılımı

\begin{tabular}{lcccccccc}
\hline & $\mathbf{2 0 0 4 - 2 0 0 7}$ & \multicolumn{2}{c}{$\mathbf{2 0 0 8 - 2 0 1 2}$} & \multicolumn{2}{c|}{$\mathbf{2 0 1 3 - 2 0 1 7}$} & \multicolumn{2}{c}{$\mathbf{2 0 0 4 - 2 0 1 7}$} \\
& f & $\mathbf{\%}$ & F & \% & f & \% & f & \% \\
\hline Türkiye kökenli & 71 & 84,5 & 125 & 85,0 & 146 & 84,4 & 342 & 84,7 \\
YD'da Türkiye kökenli & 8 & 9,5 & 4 & 2,8 & 6 & 3,4 & 18 & 4,5 \\
TR'de Yabanc1 & 2 & 2,4 & 2 & 1,4 & 3 & 1,8 & 7 & 1,7 \\
Yabanc1 & 3 & 3,6 & 16 & 10,8 & 18 & 10,4 & 37 & 9,1 \\
\hline Toplam & 84 & 100 & 147 & 100 & 173 & 100 & $\mathbf{4 0 4}$ & $\mathbf{1 0 0}$ \\
\hline
\end{tabular}

Tablo 11'e göre, dönemler arasında Türkiye kökenli yazarların oranı sabit kalırken, en büyük değişim I. ve II. dönemler arasında yabancı yazar oranında meydana gelmiştir. I. dönemde \%3,6 olan yabancı yazar oranı, 2008'den itibaren üç kat artış göstermiştir. Yabancı uyruklu yazarların dergiye toplam katkısı \%10,8'dir. Bu orandan Türkiye'de bir kurumu adres gösteren \%1,7'lik yabancı yazar oranı çıkarıldığında, Dergide makalesi yayımlanan yurtdışı adresli yabancı yazar sayısı 404 yazar içinde 37 kişi ile \%9,7'lik bir oranda gerçekleşmiştir. Diğer taraftan 37 yabancı yazarın 13'ü özel sayılarda yayımlanmış 11 makalenin yazarlarıdır. Özel sayılarda çoğunlukla davetli yazarların makalelerinin yer aldığı göz önüne alındığında, yabancı akademisyenlerin Dergiye katkısının düşük olduğu söylenebilir. Şekil 17'de Türkiye dışında Dergide yayın yapmış yazarların ülkeleri gösterilmiştir.

Şekil 17. Yabancı Makale Yazarlarının Ülkeleri

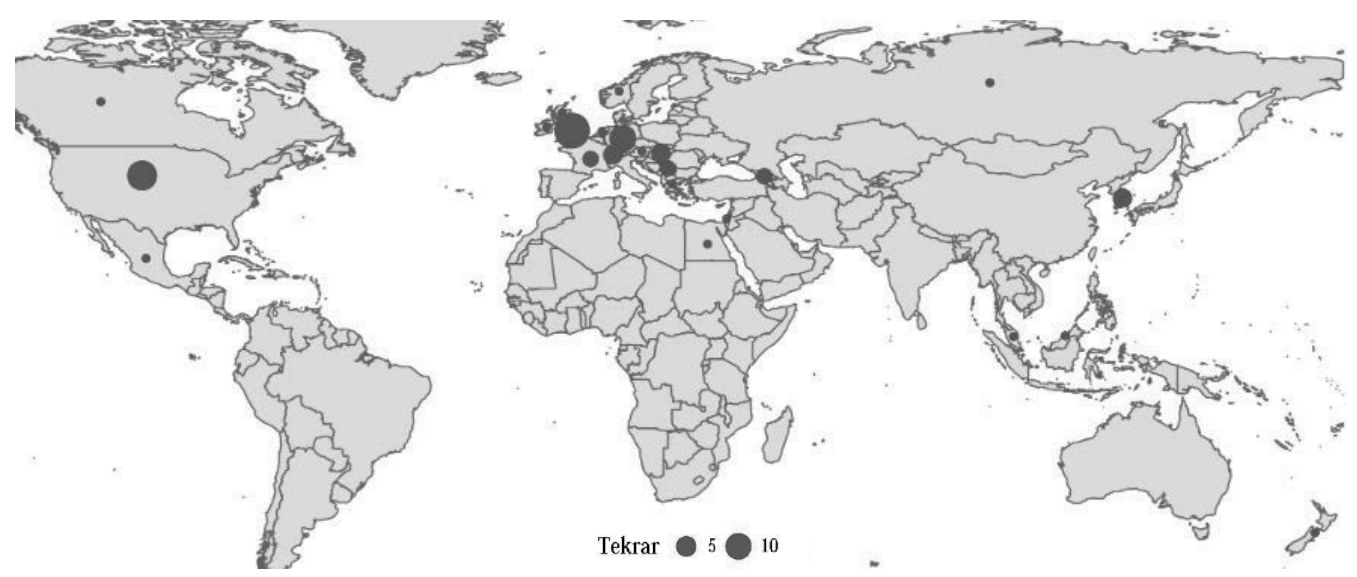

Genel içinde sayı düşük olmasına rağmen, 2008'de SSCI'da taranmaya başlamasıyla Dergide makalesi yayımlanan yabancı sayısının 5 katına, tüm yazarlar içindeki oranının ise 3 katına çıkmış olması ve haritada görüldüğü üzere 23 farklı ülkeden katılımın gerçekleşmesi, başta Avrupa'dan olmak üzere yabancı yazarların Dergiye ilgisinin artmakta olduğu şeklinde yorumlanabilir. 


\section{Yazarların Cinsiyete Göre Dağılımı}

Cinsiyetlerin dünyaya bakış açılarının farklı olduğunu ortaya koyan araştırmalar, bilim dünyasında kadın-erkek dağılımını da önemli bir konuma getirmiştir. Farklı bakış açıları, konu seçiminden metodolojiye kadar, kadın ve erkek bilim insanlarının akademik çalışmalarını etkilemektedir. ${ }^{56}$ Diğer taraftan Uİ disiplininde kadın araştırmacıların temsilinin az olduğu belirtilmektedir. ${ }^{57} \mathrm{Bu}$ durumun Dergideki yansıması Şekil 18'de gösterilmiştir.

Şekil 18. Yazarların Cinsiyetlere Göre Dağılımı

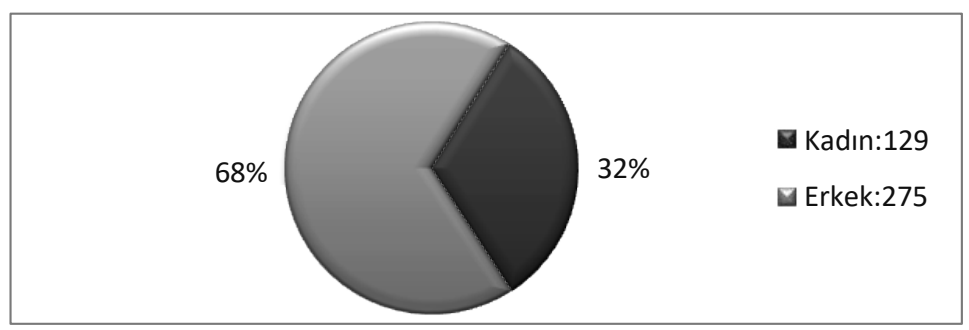

404 yazarın 129’u (\%31,9) kadın, 275’i (\%68,1) erkektir. YÖK verilerine göre 2018 yılı itibariyle Türkiye'de Uİ ve ilgili anabilim dallarında çalışan öğretim elemanlarının \%38,1'i (562) kadın, \%61,9'u (912) erkektir. ${ }^{58}$ Ayrıca TRIP 2014'e göre, Türkiye'de alandaki kadın-erkek temsili, sırasıyla \%40 ve $\% 60$ iken, dünya geneli \%33 ve $\% 67$ dir. $^{59} \mathrm{Bu}$ açıdan Dergide kadın temsilinin dünya ortalamasına yakın olmakla birlikte Türkiye rakamlarına kıyasla olması gerekenden az olduğu söylenebilir. Yazar cinsiyetlerinin dönemlere göre değişimi Şekil 19'da gösterilmiştir.

Şekil 19. Cinsiyetlerin Ylllara Göre Değişimi

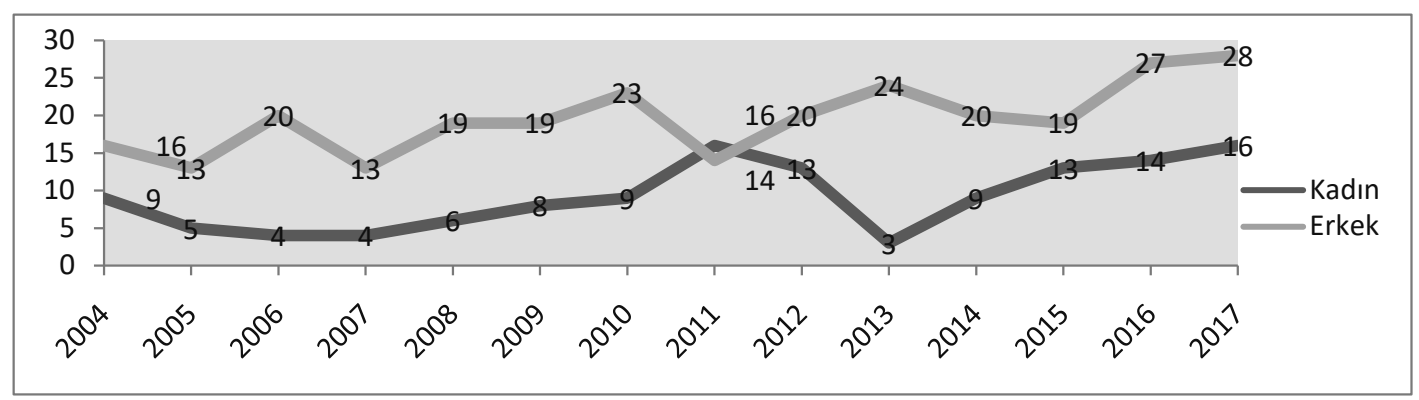

56 Örneğin ABD’de Uİ alanındaki kadın akademisyenler daha çok ulusötesi aktörler, uluslararası örgütler ve sivil toplum kuruluşları üzerine çalışırken; erkek akademisyenler dış politika ve güvenlik gibi konulara nisbeten daha fazla ağırlık vermekte; kadınlar coğrafi olarak Sahraaltı Afrika ve Latin Amerika bölgelerine yoğunlaşırken, erkekler ABD ve Avrupa bölgelerini incelemektedirler. Teori açısından da kadın-erkek akademisyenler arasında bir fark görülmektedir: Kadınlar inşacı, erkekler ise gerçekçi kuramlara kendilerini daha yakın gördüklerini ifade etmektedirler. Bu farklılık küçük de olsa metodolojik olarak da kendini göstermektedir. Nitel yöntemleri tercih ettiğini söyleyen kadın sayısı erkeklere göre az farkla fazla, çalışmalarını pozitivist olarak değerlendiren kadın sayısı ise erkeklere göre az farkla düşüktür. Bkz. Maliniak vd., Women, s. 123. Türkiye'deki mevcut durumla ilgili elimizde bir veri yoktur. Eğer Uİ eğilimlerini inceleyen TRIP araştırmalarında sorgulamalar, cinsiyet farklılıklarını gösterecek şekilde yapılırsa, Türkiye'deki durum hakkında da bu yönde bilgi elde edilebilecektir.

57 Breuning vd., Promise, s. 458; Maliniak vd., Women, s. 129; Østby vd., Gender Gap, s. 494; Aydın vd., TRIP 2014, s. 5.

58 YÖK, https://istatistik.yok.gov.tr/ (Erişim Tarihi 17 Aralık 2018).

59 Aydin vd., TRIP 2014, s. 5. 
Buna göre, erkek yazar sayısı 2011 yılı dışında sürekli olarak ve büyük farkla kadınlardan fazla iken, 2014 yılından itibaren kadın yazar sayısı istikrarlı bir artış içindedir. Bu artışla birlikte, TRIP Türkiye ve dünya geneli oranlarının altında kalan Dergideki kadın temsilinin, ilerleyen dönemlerde en azından dünya geneli rakamlarını yakalayacağı öngörülebilir.

\section{Yazarların Üniversite Türüne Göre Dağılımı}

Bilgi üretiminin birincil merkezleri üniversiteler ve araştırma merkezleri olmakla birlikte, bilhassa uluslararası örgüt ve kamu kurumu çalışanlarının uluslararası ilişkiler konularını ele alan yazılar yazmaları Uİ disiplininde yaygın bir durumdur. Bu nedenle yazarların adres gösterdikleri kurumların türüne göre dağılımı da incelenmiştir.

Şekil 20. Yazarların Kurumlara Göre Dağılımı

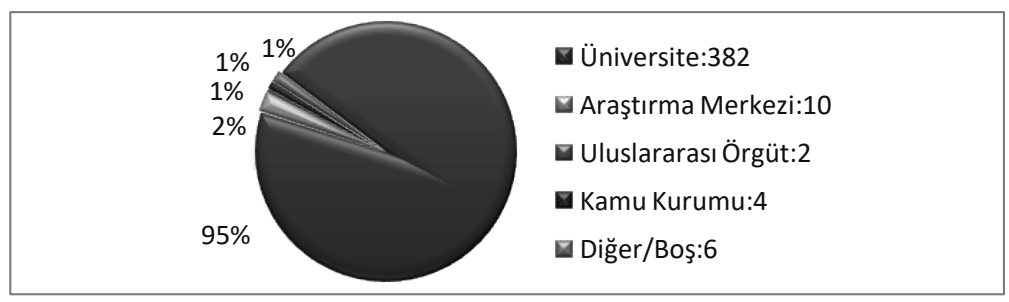

Şekil 20 incelendiğinde, yazarların \%95 gibi büyük çoğunluğunun üniversite çalışanı olduğu görülmektedir. Derginin yazar profili akademisyen ağırlıklıdır. Buradan hareketle Derginin akademisyen profilinin daha iyi anlaşılabilmesi için, yazarların görev yaptıkları üniversite türüne göre dağılımı Şekil 21'de gösterilmiştir.

Şekil 21. Üniversite Türlerine Göre Dağılım

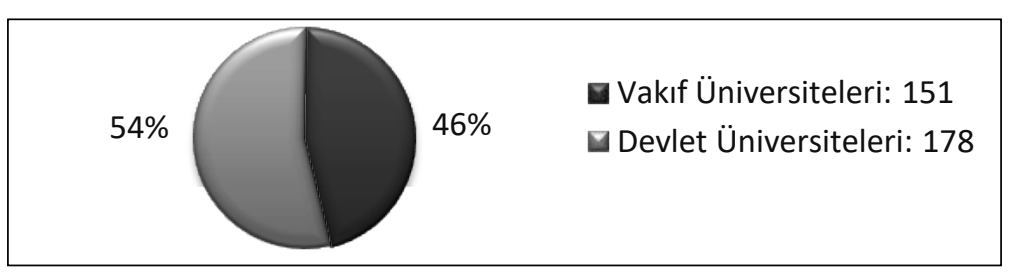

Dergi yazarlarının çalıştıkları üniversite türlerine göre dağılımında vakıf üniversitelerinin oranı $\% 45,9$ iken, devlet üniversitelerinin oranı \%54,1'dir. Üniversite türünün dönemlik dağılımı Tablo 12 'de gösterilmiştir.

Tablo 12. Üniversite Türünün Dönemlere Göre Dağılımı

\begin{tabular}{lcccccccc}
\hline & $\mathbf{2 0 0 4 - 2 0 0 7}$ & \multicolumn{2}{c}{$\mathbf{2 0 0 8 - 2 0 1 2}$} & \multicolumn{2}{c}{$\mathbf{2 0 1 3 - 2 0 1 7}$} & \multicolumn{2}{c}{$\mathbf{2 0 0 4 - 2 0 1 7}$} \\
& f & $\mathbf{\%}$ & f & $\mathbf{\%}$ & f & $\mathbf{\%}$ & f & \% \\
\hline Devlet Üniversiteleri & 50 & 70,4 & 60 & 49,6 & 68 & 49,6 & 178 & 54,1 \\
Vakif Üniversiteleri & 21 & 29,6 & 61 & 50,4 & 69 & 50,4 & 151 & 45,9 \\
\hline Toplam & $\mathbf{7 1}$ & $\mathbf{1 0 0}$ & $\mathbf{1 2 1}$ & $\mathbf{1 0 0}$ & $\mathbf{1 3 7}$ & $\mathbf{1 0 0}$ & $\mathbf{3 2 9}$ & $\mathbf{1 0 0}$ \\
\hline
\end{tabular}


Tablo 12'ye göre, Derginin I. döneminde devlet üniversiteleri lehine olan fark, II. ve III. dönemlerde kapanmış ve 2008 yılından itibaren vakıf ve devlet üniversiteleri Dergide eşit oranda temsil edilmiştir. 2018 yılı itibarıly Türkiye'de $129(\% 62,6)$ devlet, $72(\% 34,9)$ vakıf üniversitesi ve $5(\% 2,4)$ vakıf meslek yüksek okulu olmak üzere toplam 209 yüksek öğretim kurumu bulunmaktadır. ${ }^{60}$ Vakıf üniversitesi sayısının devlet üniversitesi sayısından yarı yarıya az olmasına rağmen, Dergideki yayın sayılarının bu derece yüksek olmasından hareketle, vakıf üniversitelerinde çalışan akademisyenlerin Dergiye katılım açısından daha üretken olduğu ifade edilebilir.

\section{Üniversite Üretkenliği}

2018 yılı itibarıla 206 üniversitede toplam 154 aktif Uİ bölümü vardır. ${ }^{61}$ Alana özgü SSCI'da taranan tek dergiye en çok katkıda bulunan yazarların hangi üniversitelerde çalıştığının tespiti, bir anlamda Türkiye'de Uİ disiplininin gelişimine en çok katkı sağlayan üniversitelerin de tespiti anlamına gelecektir. Dergideki en üretken üniversiteler Tablo 13'te gösterilmiştir.

Tablo 13. En Üretken Üniversiteler ${ }^{62}$

\begin{tabular}{lcc}
\hline Üniversite & f & \% \\
\hline Ankara Ü. & 26 & 8,0 \\
Kadir Has Ü. & 22 & 6,7 \\
Bilkent $\ddot{U}$. & 21 & 6,4 \\
Hacettepe Ü. & 21 & 6,4 \\
ODTÜ & 19 & 5,8 \\
Koç $\ddot{U}$. & 14 & 4,3 \\
Adnan Menderes Ü. & 10 & 3,0 \\
Sabancı Ü. & 9 & 2,8 \\
Dokuz Eylül Ü. & 8 & 2,5 \\
İstanbul Bilgi Ü. & 8 & 2,5 \\
Başkent Ü. & 7 & 2,2 \\
Fatih Ü. & 7 & 2,2 \\
İzmir Ekonomi Ü. & 7 & 2,2 \\
Galatasaray Ü. & 6 & 1,9 \\
Uludağ Ü. & 6 & 1,9 \\
Bahçeşehir Ü. & 5 & 1,5 \\
Boğaziçi Ü. & 5 & 1,5 \\
Gazi Ü. & 5 & 1,5 \\
İstanbul Kültür Ü. & 5 & 1,5 \\
Maltepe $\ddot{U}$. & 5 & 1,5 \\
Sakarya Ü. & 5 & 1,5 \\
Selçuk Ü. & 5 & 1,5 \\
TOBB Ü. & 5 & 1,5 \\
Diğer (49 üniversite) & 95 & 29,1 \\
\hline Toplam & $\mathbf{3 2 6}$ & $\mathbf{1 0 0}$ \\
\hline
\end{tabular}

60 YÖK, İstatistik.

61 YÖK, İstatistik.

62 Vakıf üniversiteleri italik olarak gösterilmiştir. Üniversite dışı kurumlar ve yabancı üniversitelerden yazarlar bu analize dahil edilmemiştir. 
Tabloya göre, Dergiye en çok katkı sağlamış üniversiteler arasında Ankara, Kadir Has, Bilkent, Hacettepe ve ODTÜ ilk beş sırada yer almaktadır. 14 tanesi vakıf olan 23 farklı üniversite, Türkiye kökenli makale yazarlarının ${ }^{63} \% 71$ 'inin çalıştığı kurumlar olmuştur. Bulgular, Dergiye katkıların büyük ölçüde İstanbul ve Ankara merkezli olduğunu göstermektedir. Üniversitelerin dergiye yaptıkları katkı oranına göre illere dağılımı Şekil 22'de gösterilmiştir.

Şekil 22. Üniversitelerin Bulundukları İllere Göre Üretkenlikleri

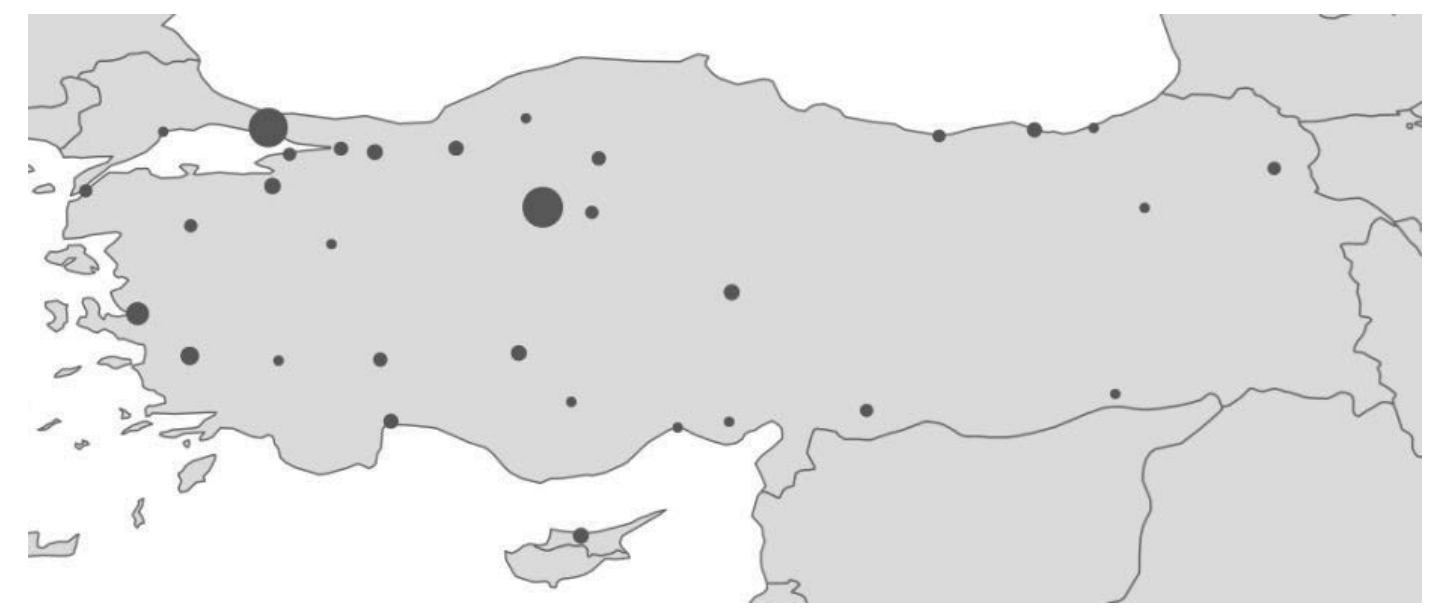

Buna göre, Marmara, İç Anadolu, Ege ve Akdeniz bölgelerinde yoğunlaşan ve 32 farklı ilde yer alan üniversiteler Dergide temsil edilmiştir. Üniversite sayısının artması ile daha fazla sayıda üniversitenin Dergide temsil edilmesi beklenirken, ${ }^{64}$ bu artışın Dergiye yansımadığı görülmektedir. $\mathrm{Bu}$ durum, her şehre üniversite açma politikasının akademik başarı ve üretkenlik getirmediğine işaret etmektedir.

İletişim çağının sağladığı akademik yayınlara kolay ulaşım imkânlarına rağmen, pek çok üniversitenin Dergide henüz hiç temsil edilmemiş olması, merkez ülkeler dışındaki ülkelerden Uİ'ye bilimsel katkı olacaksa, bu katkının o ülke/bölgelerdeki birkaç seçkin üniversitede çalışan birkaç akademisyenin tekelinde olacağını söyleyen Kristensen'in öngörüsünü haklı çıkarır niteliktedir. ${ }^{65}$ Uİ Dergisine en çok katkıda bulunan az sayıdaki üniversitenin varlı̆ğ Kristensen’in öngörüsünün ilk kısmını doğrulamaktadır. Öngörüsünün ikinci basamağı yani Uİye bilimsel katkının az sayıdaki akademisyenin tekelinde olup olmadığı sorusu ise aşağıda yazar verimliliği başlığında değerlendirilmiştir.

63 Tüm yazarlar toplamında $\% 57,2$.

64 Üniversite sayısının artmasının bir sonucu da akademisyen sayısının artmasıdır. YÖK verilerine göre, 2018 yılı itibariyle 209 üniversitedeki Uİ ve ilgili bölümlerde çalışan öğretim elemanı sayısı 1474’tür. Sezer, 2005 yılında bu sayıyı 77 üniversite ve 570 Uİ öğretim elemanı olarak vermiştir. Bkz. Duygu Bazoğlu Sezer, "Türkiye’de Uluslararası İlişkiler Çalışmalarının Bilim Dalı Olarak Gelişmesine Güncel ve Tarihsel Bir Bakış”, Türkiye’de Uluslararası İlişkiler Çalışmaları ve Eğitimi Paneli, 16-17 Nisan 2005, Uluslararası İlişkiler, Cilt 2, No 6, 2005, s. 31.

65 Kristensen, Revisiting, s. 265. 
Tablo 14. En Üretken İlk 5 Üniversitenin Dönemlere Göre Dağılımı

\begin{tabular}{lcccccccc}
\hline & \multicolumn{2}{c}{$\mathbf{2 0 0 4 - 2 0 0 7}$} & \multicolumn{2}{c}{$\mathbf{2 0 0 8 - 2 0 1 2}$} & \multicolumn{2}{c}{$\mathbf{2 0 1 3 - 2 0 1 7}$} & \multicolumn{2}{c}{$\mathbf{2 0 0 4 - 2 0 1 7}$} \\
& f & \% & f & \% & f & \% & f & \% \\
\hline Ankara Ü. & 16 & 61,6 & 6 & 13,6 & 4 & 10,3 & 26 & 23,8 \\
Kadir Has Ü. & - & - & 8 & 18,2 & 14 & 35,9 & 22 & 20,2 \\
Bilkent Ü. & 3 & 11,5 & 10 & 22,7 & 8 & 20,5 & 21 & 19,3 \\
Hacettepe Ü. & 3 & 11,5 & 12 & 27,3 & 6 & 15,4 & 21 & 19,3 \\
ODTÜ & 4 & 15,4 & 8 & 18,2 & 7 & 17,9 & 19 & 17,4 \\
\hline Toplam & $\mathbf{2 6}$ & $\mathbf{1 0 0}$ & $\mathbf{4 4}$ & $\mathbf{1 0 0}$ & $\mathbf{3 9}$ & $\mathbf{1 0 0}$ & $\mathbf{1 0 9}$ & $\mathbf{1 0 0}$ \\
\hline
\end{tabular}

Tablo 14'de verilen en üretken ilk 5 üniversiteden yayımların dönemsel dağılımına göre, Mülkiye ekolünü oluşturan Ankara Üniversitesi, yıllar içerisinde kan kaybetmesine rağmen Dergiye katkı açısından toplamda en çok yayına sahip üniversitedir. Ankara Üniversitesi'nin ilk dönemdeki üstünlügünü önce Bilkent ve Hacettepe, son dönemde ise Kadir Has Üniversitesi ele geçirmiştir. Tüm üniversitelerin yayın sayısı III. dönemde azalırken, Kadir Has artış göstererek genel toplamda ikinci sıraya yükselmiştir.

Tablo 14'deki 5 üniversite, TRIP araştırmasına göre, Türkiye kökenli Uİ akademisyenleri tarafından Türkiye'de alanda lisans ve lisansüstü eğitim alınacak en iyi üniversiteler arasında gösterilen ve bu anlamda Kristensen' in tabiriyle seçkin olarak değerlendirilebilecek üniversiteler ile uyumludur. ${ }^{66}$ $\mathrm{Bu} 5$ üniversite Dergide yayımlanan Türkiye üniversiteleri çıkışlı ${ }^{67}$ makalelerin 109 'unu $(\% 33,4)$ üretmişlerdir.

UI'de yayın yapan akademisyenlerin "seçkin" olarak nitelendirilebilecek belli üniversitelerde yoğunlaşmış olması, 'Matthew Etkisi' ile açıklanabilmektedir. 'Başarı başarıyı çeker' şeklinde özetlenebilecek bu etkiye göre; seçkin üniversiteler akademik personeline daha iyi çalışma, burs ve fonlama imkânları sağlayarak başarılı olmakta, bu başarılı okulları tercih eden daha donanımlı öğrenci ve daha kaliteli/daha çok yayın yapan öğretim üyeleri, daha büyük akademik başarıları beraberinde getirerek sarmal bir şekilde birbirini beslemektedir. ${ }^{68}$ Amerika'daki seçkin üniversitelerin sürekli artan başarı grafiğini açıklayan bu etki, Türkiye'deki seçkin üniversiteler için de geçerli görünmektedir.

\section{Yazarların Akademik Unvanlara Göre Dağılımı}

Akademik kariyerinin başında olan doktora adayları, doktor ve araştırma görevlisi gibi unvanlara sahip akademisyenlerin yayın yapma konusunda daha istekli oldukları, ${ }^{69}$ profesör ve doçent gibi yüksek unvanlı akademisyenlerin ise dergi makalesi yerine, kitap ya da proje gibi daha uzun soluklu ve kalıcı çalışmalara yöneldikleri bildirilmektedir. ${ }^{70} \mathrm{Bu}$ bilgiler ışığında Dergide yayın yapan yazarların unvanlara göre dağılımları Şekil 23 'te gösterilmiştir.

66 Aydın vd., TRIP 2014, s. 25.

67 Tüm kurumlar toplamında $\% 27$.

68 Kristensen, Revisiting, ss. 252, 265; Daniel Maliniak, Susan Peterson ve Michael Tierney, TRIP Around the World: Teaching, Research, and Policy Views of International Relations Faculty in 20 Countries, Williamsburg VA, College of William and Mary, 2012, ss. 60-62.

69 Bu nedenler; doçentlik unvanını alabilmek için Üniversiteler Arası Kurul (ÜAK) tarafından belirlenmiş yayın kriterleri ve bazı üniversitelerde lisansüstü tezlerin savunulabilmesinin bir koşulu olarak getirilmiş yayın yapma zorunluluğu olarak belirtilmiştir. Çiçek ve Kozak, Anatolia, s. 747; Breuning vd., Promise, s. 458.

70 Breuning vd., Promise, s. 458. 
Şekil 23. Yazarların Akademik Unvanlara Göre Dağılımı

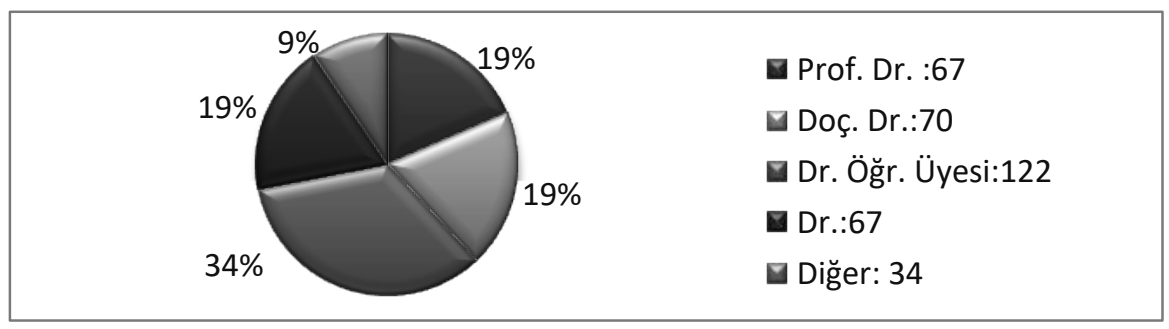

Şekil 23'e göre, Dergide en çok makale yayımlayan unvanlar sırasıyla doktor öğretim üyesi $(\% 33,9)$, doçent $(\% 19,4)$, profesör $(\% 18,6)$, doktor $(\% 18,6)$ ve diğer ${ }^{71}(\% 9,4)$ şeklinde oluşmuştur. $\mathrm{Bu}$ oranlar, yukarıda verilen beklentilerle örtüşmektedir. Dergiye en çok katkı, henüz doçentlik unvanını almamış akademisyenler tarafından yapılmakta, doktor $(\% 18,6)$ ve doktor öğretim üyelerinin $(\% 33,9)$ toplamı, Dergide yayın yapan akademisyenlerin yarıdan fazlasını $(\% 52,5)$ oluşturmaktadır. Profesör, doçent ve doktor unvanlı akademisyen oranları ise birbirleriyle aynıdır.

Özel sayılardaki unvan dağılımı genel dağılımdan farklılık göstermektedir. Dergide yayın yapmış olan toplam 67 profesörün 24’ü $(\% 35,8), 70$ doçentin 23’ü $(\% 32,8), 122$ doktor öğretim üyesinin 19 ’u $(15,6)$ ve 67 doktorun 14’ü $(\% 20,9)$ özel sayı yazarlarıdır. Oranlardaki bu farklılık, özel sayılarda davetli yazar olarak yüksek unvanlı akademisyenlerin tercih edilmiş olmasıyla açıklanabilmektedir.

Tablo 15. Akademik Unvanların Dönemlere Göre Dağılımı

\begin{tabular}{lcccccccc}
\hline & \multicolumn{2}{c}{$\mathbf{2 0 0 4 - 2 0 0 7}$} & \multicolumn{2}{c}{$\mathbf{2 0 0 8 - 2 0 1 2}$} & \multicolumn{2}{c}{$\mathbf{2 0 1 3 - 2 0 1 7}$} & \multicolumn{2}{c}{$\mathbf{2 0 0 4 - 2 0 1 7}$} \\
& $\mathbf{f}$ & $\mathbf{9}$ & $\mathbf{f}$ & $\mathbf{\%}$ & $\mathbf{f}$ & $\mathbf{\%}$ & $\mathbf{f}$ & $\mathbf{\%}$ \\
\hline Prof. Dr. & 12 & 15,0 & 21 & 16,1 & 34 & 22,6 & 67 & 18,6 \\
Doç. Dr. & 13 & 16,2 & 30 & 23,1 & 27 & 18,0 & 70 & 19,5 \\
Dr. Ö̆ğr. Üyesi & 23 & 28,8 & 43 & 33,1 & 56 & 37,3 & 122 & 33,9 \\
Dr. & 16 & 20,0 & 30 & 23,1 & 21 & 14,0 & 67 & 18,6 \\
Diğer & 16 & 20,0 & 6 & 4,6 & 12 & 8,0 & 34 & 9,4 \\
\hline Toplam & $\mathbf{8 0}$ & $\mathbf{1 0 0}$ & $\mathbf{1 3 0}$ & $\mathbf{1 0 0}$ & $\mathbf{1 5 0}$ & $\mathbf{1 0 0}$ & $\mathbf{3 6 0}$ & $\mathbf{1 0 0}$ \\
\hline
\end{tabular}

Dergide akademik unvanlara göre yayın yapma sıklığına bakıldığında (Tablo 15) ise dönemler içinde profesör ve doktor öğretim üyesi oranları sürekli artarken, doçent ve doktor unvanlarının istikrarsız bir seyir izlediği, Derginin 2008 yılında SSCI'da taranmaya başlamasıyla birlikte, araştırma görevlisi, öğretim görevlisi, uzman ve okutman kadrolarındaki akademisyenlerin oranının azaldığı görülmektedir. Bu bulgular, Dergi özelinde; hem doktor öğretim üyelerinin daha üretken olduğunu; hem de Derginin doktor öğretim üyeleri tarafından doçentlik unvanı alınıncaya kadar daha çok tercih edildiğini göstermektedir.

\section{Yazar Üretkenliği}

Dergiye en çok katkıda bulunan ya da Dergi kesitinde en üretken olarak nitelendirilebilecek yazarlar Tablo 16'da gösterilmiştir.

71 Araştırma görevlisi, öğretim görevlisi ve uzman gibi kadrolar Diğer başlığı altında toplanmıştır. 
Tablo 16. Yazar Üretkenliği $i^{72}$

\begin{tabular}{lcc}
\hline Yazar & f & \% \\
\hline Mustafa AYDIN $^{72}$ & 9 & 2,8 \\
Faruk YALVAÇ & 6 & 1,9 \\
Sinem AKGÜL AÇIKMEŞE & 5 & 1,6 \\
Ali L. KARAOSMANOĞLU & 4 & 1,3 \\
Mert BİLGİN & 4 & 1,3 \\
Mitat ÇELİKPALA & 4 & 1,3 \\
\hline Toplam & $\mathbf{3 2}$ & $\mathbf{1 0 , 2}$ \\
\hline
\end{tabular}

Tablo 16'daki 6 yazar, Dergide yayımlanan 316 makalenin 32'sinin (\%10,2) yazarıdır. Bu yazarlar dışında 12 yazarın üç, 37 yazarın ise iki farklı makalesi yayımlanmıştır. Dergide birden fazla makalesi yayımlanmış yazar sayısı 55, tek bir makalede ismi geçen yazar sayısı 264'tür. Bir diğer ifadeyle, Dergide birden fazla yayın yapmış olan toplam 55 yazar, Derginin \%44'ünü çıkarmış, kalan \%56'lık kısmı ise 264 yazar tarafından yazılmıştır. Kristensen'in yukarıda bahsedilen, çevre ülkelerde Uİye katkı sağlamanın birkaç seçkin üniversiteden birkaç seçkin akademisyenin tekelinde kalacağı öngörüsünün ikinci basamağı da bu veriler ışığında doğrulanmış görünmektedir. ${ }^{73}$

\section{Sonuç}

Bu araştırmada, Türkiye'deki Uİ disiplini çalışmalarının, SSCI'da taranan Türkiye çıkışlı alana özgü tek dergi olan Uİ dergisine nasıl yansıdığı incelenmiştir. Tek bir derginin sonuçları geneli yansıtmasa da, disiplinin bir kesitini ortaya koyması bakımından önemlidir. ${ }^{74}$ Yazarların büyük çoğunluğunun $(\% 89,2)$ Türkiye kökenli olması, Derginin Türkiye Uİ akademisyenlerinin çalışmalarını yansıttığı şeklinde yorumlanabilir. Böylelikle Derginin kadrajından Türkiye'deki Uİ disiplininin bir fotoğrafı da çekilmiş olmaktadır.

Araştırma sonuçları değerlendirilirken, basılı makalelerin değerlendirildiği, bu makalelerin yazarlar, hakemler ve editörlerin ortak kararlarına bağlı olarak son şekillerini almış oldukları, Dergiye gönderilen ancak reddedilen veya "oto-sansür" nedeniyle yazarların hiç göndermedikleri ya da başka dergilerde yayımlatmayı tercih ettikleri araştırmaların sonuçları değiştirme potansiyeline sahip olduğu hatırlanmalıdır. $^{75}$

Makaleler genel olarak değerlendirildiğinde, 2008 yılından itibaren Dergiye artan bir talep olduğu, en çok Uİ disiplininden, Uİ ana bilim dalından ve akademisyen bir kitle tarafından tercih edildiği, kuramsal çalışmalardan ziyade vaka analizi araştırmalarının yer aldığı görülmektedir. Derginin zaman içinde alanın disiplinlerarası yapısını daha iyi yansıtacak şekilde yeni konulara yer verdiği, yazarların ise konu ve coğrafya seçimlerinde ulusal/yerel eğilimlere sahip oldukları görülmüştür. Araştırmacıların üzerinde en çok çalıştığı konular uluslararası güvenlik ve Türk dış politikasıdır. Bu bağlamda Dergi küresel Uİ disiplininin genel eğilimleri ile paralellik göstermektedir. Ancak teori

72 Uluslararası İliş̧kiler Konseyi tarafından yürütülen ve Dergide yayımlanan TRIP araştırmaları hakkındaki 3 makale, Mustafa Aydın'ın üretkenlik oranını artıran bir etmendir.

73 Kristensen, Revisiting, s. 265.

74 Breuning vd., Promise, s. 459.

75 Ibid, s. 460. 
araştırmalarında birinci büyük tartışmanın ötesine geçilemediği, metodolojik ve epistemolojik konu ve yöntemlere hemen hiç yer verilmediği görülmüştür. Bu durum, Türkiye’nin Dergi aracılığıyla küresel kuramsal çalışmalara ve büyük tartışmalara yapacağı katkıyı sınırlayan bir unsurdur.

Yazarlar genel olarak değerlendirildiğinde, bilginin seçkin olarak tanımlanabilecek sınırlı sayıda üniversitede çalışan, az sayıda akademisyen tarafından üretildiği görülmektedir. Devlete kıyasla vakıf üniversitelerinin, küçük şehirlere kıyasla büyük şehirlerde yer alan üniversitelerin, yeni açılanlara kıyasla eski üniversitelerin daha üretken oldukları, üretkenliğin batıdan doğuya gidildikçe azaldığı, en üretken akademisyen grubunun doktor öğretim üyeleri olduğu ve kadın akademisyen temsilinin nispeten az olduğu da tespit edilmiştir.

Önemli bir bilimsel mecra olan Derginin bibliyometrik analizi, Türkiye’deki Uİ disiplininin kayda değer bir kesitini yansıtmaktadır. Ancak disiplinin geneli hakkında daha net bilgi sahibi olabilmek, bibliyometrik analizlerin farklı dergi ve kitapları da kapsayacak şekilde karşılaştırmalı olarak genişletilmesi ve belli aralıklarla tekrarlanması ile mümkündür. Ayrıca, küçük bir azınlığın büyük miktarda bilgi ürettiği Dergide, bilgiyi üreten bu yazarların kimleri okuduğunu, Dergide sunulan bilginin kimler tarafından kullanıldığını tespit edebilmek için atıf analizleri ve ele alınan konuların hangi bağlamlarda çalışıldığını anlamak için de içerik analizlerinin yapılması faydalı olacaktır. 